\section{A REVIEW ON THE POLLINATION OF AROIDS WITH BISEXUAL FLOWERS 1}

Pedro Díaz Jiménez, ${ }^{2 *}$ Heiko Hentrich, ${ }^{3}$

Pedro Adrián Aguilar-Rodríguez, ${ }^{2}$

Thorsten Krömer, ${ }^{2}$ Marion Chartier, ${ }^{4}$

M. Cristina MacSwiney G., ${ }^{2}$ and Marc Gibernau ${ }^{5}$

\begin{abstract}
This paper presents an exhaustive review of the current knowledge on pollination of Araceae genera with bisexual flowers. All available studies on floral morphology, flowering sequence, floral scent, floral thermogenesis, floral visitors, and pollinators were carefully examined, with emphasis on the species-rich genera Anthurium Schott, Monstera Adans., and Spathiphyllum Schott. Genera with bisexual flowers are among the early-diverging lineages in Araceae, but present adaptations in their floral ecology to a great variety of pollination vectors, such as bees, beetles, flies, and, unusually, wind. These clades have developed highly derived pollination systems, involving the use of floral scent as a reward. We conclude that floral scent chemistry plays a key role in the pollination biology of the plants and that, in some genera, reproductive isolation through variation in the emitted floral volatile compounds may have been the decisive factor in the speciation processes of sympatric species.
\end{abstract}

Key words: Anthurium, Araceae, bee pollination, beetle pollination, floral scent, fly pollination, Monstera, Spathiphyllum.

Araceae is a plant family that belongs to the order Alismatales, comprising over 3600 species and 144 genera (Boyce \& Croat, 2018). Its species are distributed worldwide, with more than two thirds of all taxa occurring in the Neotropics (Bown, 2000). Most aroids are climbers, epiphytes, and terrestrials, whereas a few are aquatic (Croat, 1988, 1998). They develop inflorescences composed of an unbranched spike bearing the flowers, named spadix, which is surrounded by a modified bract called spathe. All aroids are protogynous, and the female (stigma receptivity) and male (anther dehiscence) phases rarely overlap so that obligate outcrossing seems to be the rule in this family (Mayo et al., 1997).

The late-diverging subfamily Aroideae (Fig. 1) is the only taxonomic group that bears unisexual flowers and a spathe that encloses the spadix (almost always toward the base, where the female flowers are located), forming a simple or complex floral chamber (i.e., Philodendron Schott and Cryptocoryne Fisch. ex Wydler; Mayo et al., 1997). The pollination in Aroideae usually takes place within the floral chamber during a short flowering sequence (one to a few days). Heat (floral thermogenesis) and volatile organic compounds (VOCs) have been shown to be important for the attraction of the pollinators (cyclocephaline beetles or flies), which stay for a long time (up to 48 hours) inside the floral chamber. During their stay, the beetles copulate, heat up their bodies, and eat pollen, floral tissues, or floral exudates (Gibernau, 2003, 2011; Gibernau et al., 2010a). For the flies, the most common reward is the provision of an ovipositing site, although they also eat pollen and/or spadix secretions (Gibernau et al., 2010a; Bröderbauer et al., 2012). However, besides mutualisms, some species have also evolved deceptive strategies, where pollinators stay in the floral chamber but are not rewarded at all (Gibernau et al., 2010a; Bröderbauer et al., 2012; Chartier et al., 2014).

In this review, we focus on the pollination mechanisms of Araceae genera having bisexual (= hermaphroditic) flowers. Within the family, only the early-diverging clades (i.e., subfamilies Gymnostachydoideae, Orontioideae, Lemnoideae, Pothoideae, Monsteroideae, and Lasioideae; Fig. 1) bear bisexual flowers and a persistent spathe that in most cases leaves the spadix with the flowers exposed (Cabrera et al., 2008; Cusimano et al., 2011). Some subfamilies, like Pothoideae, encompass species-rich genera, such as Anthurium Schott, whereas

\footnotetext{
1 We are grateful to Valeria Guzmán Jacob, Adrienne Godschalx, and Julia Basler for their valuable comments on the manuscript; Lilia Ruiz-Ruiz for preparing Figure 2; and the guest editor for the invitation to submit the manuscript to the special aroid issue of the Annals of the Missouri Botanical Garden. The manuscript has been significantly improved by the helpful comments and suggestions of three anonymous reviewers. This work was supported by the Consejo Nacional de Ciencia y Tecnología (CONACYT), grant number 59406, awarded to Pedro Díaz Jiménez.

2 Centro de Investigaciones Tropicales, Universidad Veracruzana, José María Morelos No. 44 y 46, Zona Centro, C.P. 91000, Xalapa, Veracruz, Mexico.

${ }^{3}$ Deutsche Homöopathie-Union, Ottostrasse 24, D-76227 Karlsruhe, Germany.

${ }^{4}$ Department of Botany and Biodiversity Research, University of Vienna, Rennweg 14, Vienna, Austria.

5 CNRS-University of Corsica, Laboratory Sciences for the Environment (UMR 6134), Natural Product Project, Vignola - Route des Sanguinaires, F-20000 Ajaccio, France.

* Author for correspondence: aroid764@hotmail.com
} 


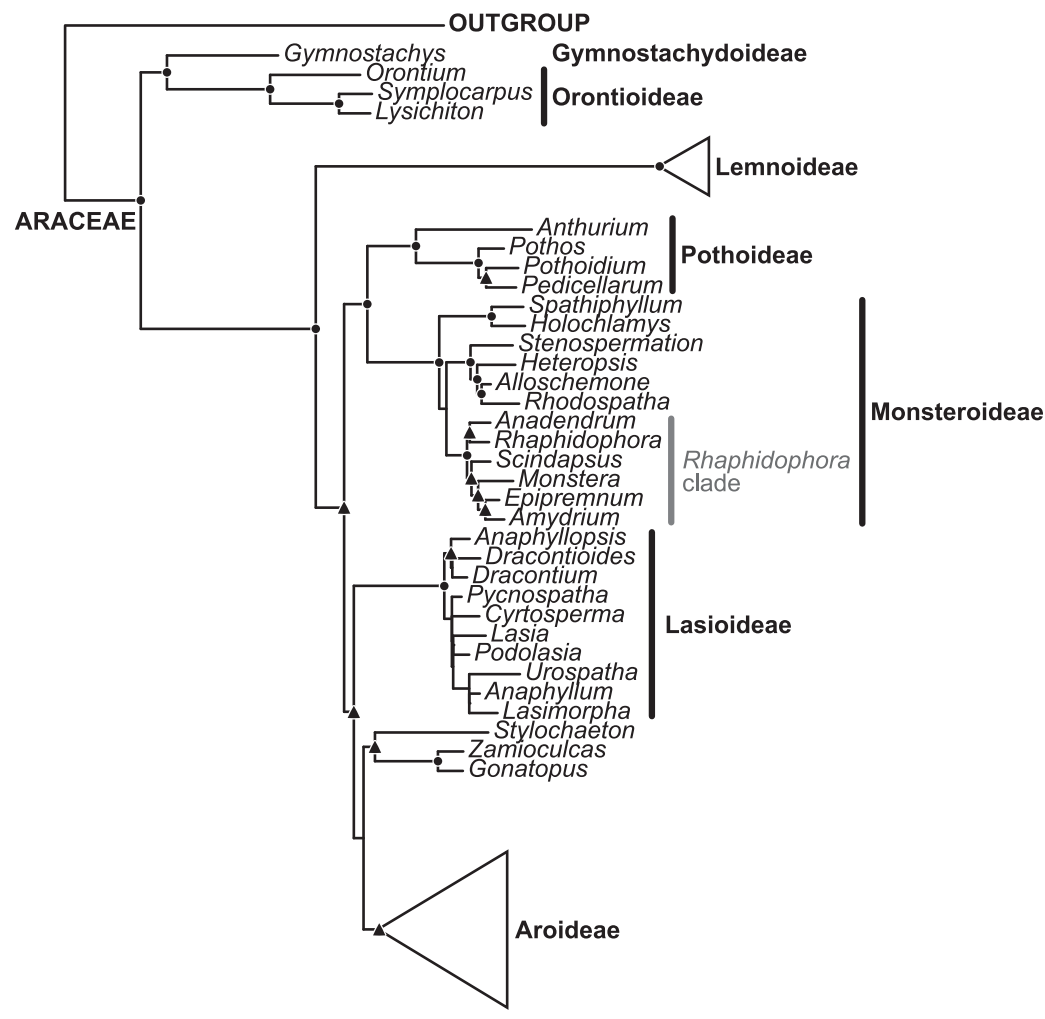

Figure 1. Phylogeny of the Araceae showing in detail the genera in subfamilies with bisexual flowers (genera not indicated in Lemnoideae). Black triangles: clades supported in Cusimano et al. (2011); black circles: clades supported in both Cusimano et al. (2011) and Chartier et al. (2014). Figure modified, with permission, from Chartier et al. (2014). Note that Calla could either be included in Aroideae or sister to it, but its position remains uncertain.

others, e.g., Gymnostachydoideae, are monotypic (Mayo et al., 1997). These plants (including the monotypic genus Calla L., possibly included in Aroideae or sister to it, but whose position remains uncertain; see Ulrich et al., 2013; Chartier et al., 2014) encompass 31 genera and about 1500 species (Mayo et al., 1997; Boyce \& Croat, 2018). In contrast to taxa with unisexual flowers, their pollination mechanisms are still poorly understood (Mayo et al., 1997; Hentrich et al., 2010). The available information is scarce and scattered for some genera, nonexistent for others, and even contradictory in some cases (Gibernau, 2011, 2016).

Usually, aroids with bisexual flowers have a long flowering sequence (i.e., sexual phases can last several days), with a female phase shorter than the male phase (at least in documented cases, except in Monstera Adans.). Their floral morphology is less elaborate, with exposed rewards available for every floral visitor (Mayo et al., 1997). The rewards include pollen, stigmatic exudates, floral tissues, floral scent, heat, sites for mating, ovipositing, or breeding, and even refuge provided by the spathe (Croat, 1980; Montalvo \& Ackerman, 1986; Pellmyr \& Patt, 1986; Schwerdtfeger et al., 2002; Chouteau et al., 2007; Hentrich et al., 2010; Etl et al.,
2017; Prieto \& Cascante-Marín, 2017). As documented in the subfamily Aroideae, the floral odor composition in bisexual aroids is also likely to be decisive for pollinator attraction (Williams \& Dressler, 1976; Schwerdtfeger et al., 2002; Hentrich et al., 2010; Etl et al., 2017), and the scent emission cycles can vary throughout anthesis (Kuanprasert et al., 1998; Kuanprasert \& Kuehnle, 1999; Hentrich et al., 2007). In addition, the color of the spathe/spadix is also considered important for the attraction of specific groups of pollinators in some genera (e.g., Anthurium, Dracontium L.; Croat, 1975, 1980). Information about thermogenesis is scarce, being reported only in Anaphyllopsis A. Hay, Monstera, and Symplocarpus Salisb. ex W. P. C. Barton (Uemura et al., 1993; Seymour, 2004; Chouteau et al., 2007, 2009; Gibernau et al., 2010b).

Observations of pollinators and/or floral visitors of aroids with bisexual flowers have only been documented in about $6 \%$ of all known species, with most records restricted to the genera Anthurium, Monstera, and Spathiphyllum Schott (Table 1). The current knowledge is mostly based on a limited number of detailed studies (e.g., Montalvo \& Ackerman, 1986; Chouteau et al., 2007; Hentrich et al., 2010; Etl et al., 2017; Prieto \& 
Table 1. A comparison of the current total number of species in each aroid genus with bisexual flowers to the amount of species for which data on pollinators or comprehensive pollination studies have been published.

\begin{tabular}{lrcc}
\hline \hline & & $\begin{array}{c}\text { No. of species } \\
\text { with pollinator } \\
\text { observations } \\
\text { published } \dagger\end{array}$ & $\begin{array}{c}\text { No. of species } \\
\text { with detailed } \\
\text { pollination } \\
\text { studies } \\
\text { published } \neq\end{array}$ \\
\hline Anthurium & 950 & 55 & 6 \\
Spathiphyllum & 49 & 12 & 4 \\
Monstera & 38 & 3 & 2 \\
Symplocarpus & 5 & 2 & 1 \\
Anaphyllopsis & 3 & 1 & 1 \\
Lysichiton & 2 & 2 & 1 \\
Calla & 1 & 1 & 1
\end{tabular}

* According to Boyce and Croat (2018), only includes published species.

$\uparrow$ See Supplementary Appendix S1 for details of these studies.

* Detailed pollination studies are here considered as comprehensive investigations of the floral ecology of a species, with several days of in situ observations of the flowers and the critical distinction between floral visitors and pollinators.

Cascante-Marín, 2017). Our aim is to synthesize the scarce and somewhat dispersed information on the topic by providing an exhaustive review of the present facts on pollination of aroids with bisexual flowers. We start with a detailed description of the floral ecology of the genera and then present the different vectors pollinating them.

\section{Current Knowledge on Floral Ecology in Aroids WITH Bisexual Flowers}

Within the 31 known genera of aroids with bisexual flowers, the most comprehensive information about pollination systems comes from some species of Lysichiton Schott, Symplocarpus, Anthurium, Spathiphyllum, and Monstera, as well as one species of Anaphyllopsis and the only species of Calla (Table 1). For these genera, we describe their floral morphology, flowering phenology, attractants, mating system, and main floral visitors and pollinator groups reported in the literature. A comprehensive summary, where we list all data available for the floral ecology and the floral visitors of all species for which information was available, is given in Supplementary Appendix S1. Genera with scarce or practically absent information are grouped under the heading "Other genera" within each subfamily listed.

\section{SUBFAMILY GYMNOSTACHYDOIDEAE}

Floral ecology and pollination studies are absent for the only genus in this subfamily, Gymnostachys R. Br., an Australian endemic.

\section{SUBFAMILY ORONTIOIDEAE}

\section{Lysichiton}

Lysichiton is a terrestrial genus that comprises only two species, which are distributed in temperate regions of eastern Asia (L. camtschatcensis (L.) Schott) and western North America ( $L$. americanus Hultén \& H. St. John) (Mayo et al., 1997; Nie et al., 2006). The inflorescence sits on an erect and elongated peduncle. In both species, the spathe is cucullate to boat-shaped, the lower part narrowly convolute, and the upper part expanded. The color of the spathe is yellow in $L$. americanus (Fig. 2A) and white in L. camtschatcensis (Mayo et al., 1997). The spadix is subcylindrical and yellow or green at anthesis. In the flowers, the pistil exceeds the tepals (Grayum, 1985; Mayo et al., 1997).

The flowering sequence has only been documented in Lysichiton americanus and lasts five to 21 days (cited as “L. americanum"; Pellmyr \& Patt, 1986; Willson \& Hennon, 1997). In this species, the stigmas of all flowers are receptive at the onset of the female phase (ca. seven days; Pellmyr \& Patt, 1986; Willson \& Hennon, 1997). Subsequently, the male phase (four to 18 days) begins with an acropetal emergence of few anthers per flower and the release of pollen. At the end of the female phase, there is a temporal overlap of one or two days with the male phase, suggesting possible self-pollination (Pellmyr \& Patt, 1986).

Neither species of Lysichiton are thermogenic (ItoInaba et al., 2009a; Brousil et al., 2015). The inflorescences (spadix and spathe) of $L$. americanus emit an unpleasant odor of carrion or feces from the first day of flowering, which gradually vanishes toward the end of anthesis (Pellmyr \& Patt, 1986; Brodie et al., 2018). Among various floral scent compounds found, (E)-4nonene, (E)-5-undecene (lipid-derived compounds), and indole (nitrogen-containing compound) have proven to be the major attractants for the pollinators in electrophysiological and behavioral experiments (Brodie et al., 2018). In L. camtschatcensis, composition and emission time of the floral scent have not been documented.

According to the published studies, Lysichiton has a mixed mating system (cross- and self-pollination), including cross-pollination by beetles (Staphylinidae), flies (Anthomyiidae, Lauxaniidae), or wind (Pellmyr \& Patt, 1986; Willson \& Hennon, 1997; Tanaka, 2004; Brousil et al., 2015). Self-pollination capacity was $100 \%$ in $L$. americanus and approximately $30 \%$ in L. camtschatcensis (Pellmyr \& Patt, 1986; Tanaka, 2004). Unfortunately, limited data available for the latter species complicate the interpretation of the low fruit-set.

\section{Symplocarpus}

The genus Symplocarpus is terrestrial and currently encompasses five species, which are distributed in 


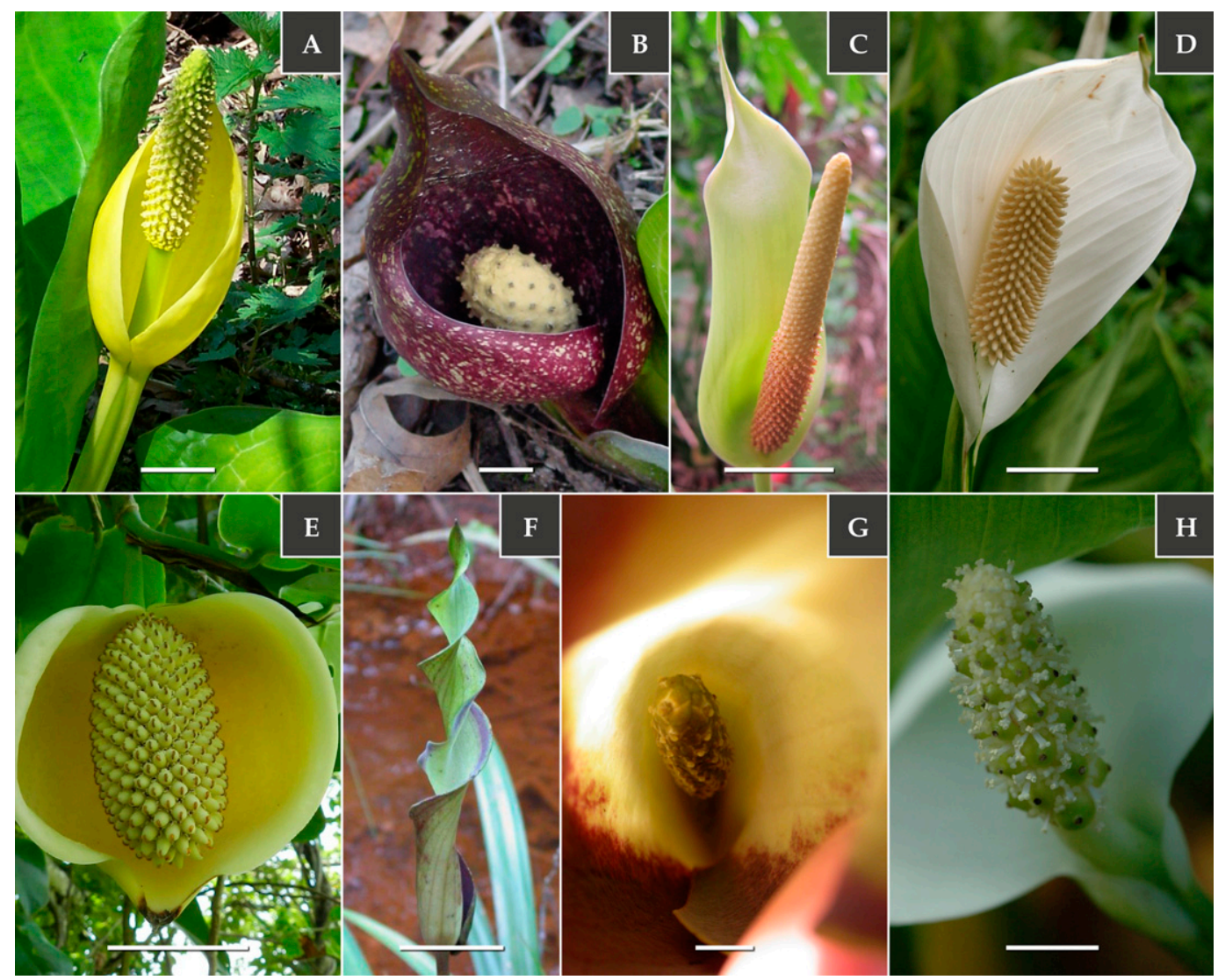

Figure 2. Inflorescences of aroids with bisexual flowers. - A. Lysichiton americanus Hultén \& H. St. John. —B. Symplocarpus foetidus (L.) Salisb. ex W. P. C. Barton. —C. Anthurium faustomirandae Pérez-Farr. \& Croat. —D. Spathiphyllum friedrichsthalii Schott. -E. Monstera tuberculata Lundell. —F. Spathe of Anaphyllopsis americana (Engl.) A. Hay. —G. Spadix of Anaphyllopsis americana. - H. Calla palustris L. Photos: A by A. Lebreton; B by M. J. Hatfield; C, E by P. Díaz Jiménez; D by H. Hentrich; F-H by M. Gibernau. Scale bars: A, C-F $=5 \mathrm{~cm} ; \mathrm{B}, \mathrm{G}, \mathrm{H}=1 \mathrm{~cm}$.

temperate regions of eastern Asia and North America (Nie et al., 2006; Boyce \& Croat, 2018). The inflorescence is located on a short, erect peduncle that emerges low to the ground. The spathe is generally dark or mottled purple, conchiform, convolute in its lower part, and wide open in its upper part with the apex rostrate and curved forward (Fig. 2B). The spadix is subglobose, gray or yellowish to purplish, and partially exposed or sometimes completely hidden within the spathe. The flowers have a pistil that projects above the tepals (Mayo et al., 1997).

So far, the pollination biology of only two Symplocarpus species has been studied, S. foetidus (L.) Salisb. ex W. P. C. Barton and S. renifolius Schott ex Tzvelev. Both species bloom in early spring, usually when there is still a considerable amount of snow on the ground. The flowering sequence of $S$. renifolius ( $=S$. foetidus var. latissimus Makino ex H. Hara; Lee et al., 2010) lasts 15 to 40 days (Uemura et al., 1993). Once the spathe opens, from the middle section toward the base, it expands to form a groove between the asymmetrical margins. The maturation of the stigmas and the emergence of the anthers are progressively basipetal. The duration of the female and male phases is highly variable among individuals, but generally the female phase lasts two to 21 days and the male phase four to 25 days. The female and male phases overlap for one to three days, but there is no support for self-pollination (Uemura et al., 1993).

Thermogenesis in Symplocarpus foetidus and S. renifolius has been extensively studied (Knutson, 1972; Camazine \& Niklas, 1984; Uemura et al., 1993; Seymour \& Blaylock, 1999; Ito et al., 2004; Seymour, 2004; Seymour et al., 2009). The spadix of both species produces heat (higher at night than during the day in $S$. renifolius) primarily throughout the female phase and in the overlapping of phases, reaching temperatures even $14^{\circ} \mathrm{C}$ higher than the ambient air (Knutson, 1972; Uemura et al., 1993). After the onset of the male phase, the temperature drops sharply (Uemura et al., 1993; Seymour \& Blaylock, 1999; Ito-Inaba et al., 2009b). In 
both species, thermogenesis has been assumed to attract and/or reward pollinators (Moodie, 1976; Knutson, 1972, 1979; Thorington, 2000) and act as a heating scent diffuser for VOCs. However, some authors also suggested that heat production might not be related to cross-pollination but could rather be the by-product of the evolution of the genus from a warm to a cold temperate climate (i.e., protection of the inflorescence from damage by frost or boosted growth in spring resulting in earlier flowering; Knutson, 1972, 1979; Seymour \& Blaylock, 1999).

Depending on the olfactory perception of each author, a wide variety of odors, pleasant or unpleasant, has been reported in Symplocarpus foetidus, being emitted by both spathe and spadix. The spathe smells like apple (sweetish), turnip, or garlic, while the spadix emits a scent that is similar to mammalian feces or carrion (Knutson, 1979; Camazine \& Niklas, 1984; Kevan, 1989). The unpleasant odor of the spadix is dominated by dimethyl disulfide (Kozen, 2013) (Table 2). Temporal patterns of odor emission throughout anthesis and diurnal and nocturnal variations are unknown. The inflorescences of $S$. renifolius emit an unpleasant odor resembling carrion, which has been identified only during the female phase and when both phases overlap (Uemura et al., 1993). However, the chemical composition of the floral scent has not been determined.

Similar to Lysichiton, the two Symplocarpus species studied were proposed to have a mixed mating system. However, Uemura et al. (1993) determined that in $S$. renifolius self-pollination is ineffective and crosspollination crucial for the production of fruits and seeds. Different visitors (e.g., beetles, crickets, flies, mosquitoes, and spiders) have been reported in S. renifolius, but only beetles (Staphylinidae) and flies (including Anthomyiidae, Fanniidae, Lauxaniidae, Simuliidae mentioned as "mosquitoes," and Syrphidae) were considered potential pollinators (Uemura et al., 1993; Hong \& Sohn, 2003). Cross-pollination is also mandatory for the reproduction of $S$. foetidus, where a wide variety of arthropods (e.g., bees, beetles, flies, spiders, springtails, stoneflies, and thrips) were reported to visit the inflorescences (Knutson, 1979; Camazine \& Niklas, 1984; Kevan, 1989; Thorington, 2000) but only stoneflies (Nemouridae, Plecoptera) had contact with flowers of both sexual phases (Thorington, 2000).

\section{Other genera in Orontioideae}

Information on floral ecology and pollinators is scarce for Orontium L., a monotypic genus restricted to the eastern United States. Bees, flies, or even beetles might be putative pollinators for the genus, although only dragonflies have been observed on their inflorescences (Grayum, 1985; Klotz, 1992).

\section{SUBFAMILY POTHOIDEAE}

\section{Anthurium}

Anthurium is a Neotropical genus comprising 950 described and more than 2000 estimated species of terrestrials, holo-epiphytes, and hemiepiphytes (Boyce $\&$ Croat, 2018). It is one of the most morphologically diverse and taxonomically complex aroid genera (Mayo et al., 1997), which makes it difficult to give a comprehensive summary of its pollination ecology. The great morphological diversity is probably an adaptation to different groups of pollinators and life forms of these aroids. The data presented here can therefore only be seen as the tip of the iceberg of information on pollination for this genus.

The spadices and spathes of Anthurium species are of different shapes, sizes, and colors. The inflorescence sits on an erect or pendant peduncle that can be either elongated or short. In most species, the spathe is pendant or reflexed, but in some cases it is also held over the erect spadix (Croat, 1980; Mayo et al., 1997) (Fig. 2C). The spathe can be linear-lanceolate, ellipticovate, or cordate to suborbicular, and its color also varies widely among different species (e.g., greenish, dark purple, brownish, cream, or showy red with a glossy appearance) (Madison, 1979; Croat, 1980, 1983; Kraemer \& Schmitt, 1999). The spadix is usually cylindric to conic (rarely clavate or globose) and short to very long (Croat, 1980, 1983). Its color can be cream, dark purple, green, lavender, reddish violet, or yellow (e.g., A. faustomirandae Pérez-Farr. \& Croat) (Fig. 2C). The flowers have a pistil of equal length to or longer than the tepals at anthesis (Croat, 1980, 1983; Mayo et al., 1997).

The duration of the flowering sequence is quite variable. It ranges from one week to over 30 days and tends to increase with the number of flowers per inflorescence (Croat, 1980; Hentrich et al., 2010). Flowering starts with a highly variable female phase, the duration of which depends on the species. For example, in Anthurium ravenii Croat \& R. A. Baker the female phase takes a few hours only, but up to a month or more in A. luteynii Croat (Croat, 1980). Most publications describe the simultaneous beginning of stigma receptivity of all flowers of the spadix, while others report species (e.g., A. sagittatum (Sims) G. Don, A. scandens (Aubl.) Engl.) in which stigmas of the flowers in the upper third of the spadix are not exposed and seem to be functionally male (Croat, 1980; Valerio \& Villalobos, 1980; Hentrich et al., 2010). In some species, droplets of stigmatic fluid may be produced in the female phase (Croat, 1980, Valerio \& Villalobos, 1980); while in others, stigmas just have a moist appearance (e.g., A. acutifolium Engl., A. armeniense Croat, A. ochranthum K. Koch), indicating their receptivity (Croat, 1980; Etl et al., 2017). 
Table 2. Floral scent composition and pollinator species published for Araceae with bisexual flowers. Only data from publications that presented both types of information (i.e., confirmed pollinating species or at least the tribe and floral scent composition) are included.

\begin{tabular}{|c|c|c|c|}
\hline Species & Main compounds of floral scent* & $\begin{array}{l}\text { Pollinator species } \\
\text { (family or tribe) }\end{array}$ & References \\
\hline $\begin{array}{l}\text { Lysichiton americanus } \\
\text { Hultén \& H. St. John }\end{array}$ & $\begin{array}{l}(E)-4 \text {-nonene }{ }^{\mathrm{L}} ;(E)-5 \text {-undecene }{ }^{\mathrm{L}} \text {; } \\
\text { indole }^{\mathrm{N}}\end{array}$ & $\begin{array}{l}\text { beetles: Pelecomalius } \\
\text { testaceum (Staphylinidae) }\end{array}$ & $\begin{array}{l}\text { Pellmyr \& Patt, } \\
\text { 1986; Brodie } \\
\text { et al., } 2018\end{array}$ \\
\hline $\begin{array}{l}\text { Anthurium acutifolium } \\
\text { Engl. }\end{array}$ & $\begin{array}{l}\text { (E)-megastigm-7-en-3,9-dione }{ }^{\mathrm{T}} ; \\
\text { 9-hydroxymegastigm-7-en-3-one } \\
\text { isomer }^{\mathrm{T}} ; \text { dodecyl acetate } \\
\text { tetradecyl acetate }^{\mathrm{L}} ; \text { indole }^{\mathrm{N}}\end{array}$ & $\begin{array}{l}\text { bees: Paratetrapedia } \\
\text { chocoensis (Tapinotaspidini) }\end{array}$ & Etl et al., 2017 \\
\hline $\begin{array}{l}\text { Anthurium apaporanum } \\
\text { R. E. Schult. }\end{array}$ & $\begin{array}{l}\text { caryophyllene }{ }^{\mathrm{T}} \text {; } \text { cubebol }^{\mathrm{T}} \text {; cadina-4,10 } \\
\text { (15)-dien-3-one }{ }^{\mathrm{T}} \text {; eugenol }{ }^{\mathrm{B}}\end{array}$ & bees: Euglossini & $\begin{array}{r}\text { Schwerdtfeger } \\
\text { et al., } 2002\end{array}$ \\
\hline Anthurium hookeri Kunth & $\begin{array}{l}\text { isoamyl alcohol }{ }^{\mathrm{L}} \text {; acetoine }{ }^{\mathrm{L}} ; 2,3- \\
\text { butandiol }^{\mathrm{L}} \text {; phenylethyl alcohol }\end{array}$ & flies: Drosophilidae & $\begin{array}{r}\text { Schwerdtfeger } \\
\text { et al., } 2002\end{array}$ \\
\hline $\begin{array}{l}\text { Anthurium moonenii Croat } \\
\text { \& E. G. Gonç. } \\
\text { (misidentified as } \\
\text { A. thrinax Madison) }\end{array}$ & 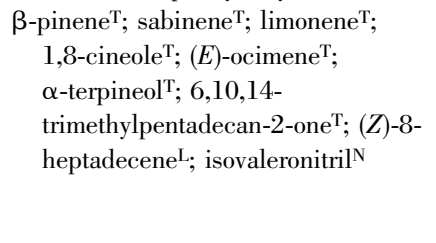 & $\begin{array}{l}\text { bees: Euglossa hemichlora, } \\
\text { Euglossa intersecta, } \\
\text { Euglossa mourei, Euglossa } \\
\text { piliventris, Euglossa prasina, } \\
\text { Eulaema bombiformis, } \\
\text { Exaerete frontalis } \\
\text { (Euglossini) }\end{array}$ & $\begin{array}{l}\text { Hentrich et al., } \\
2010\end{array}$ \\
\hline $\begin{array}{l}\text { Anthurium ochranthum K. } \\
\quad \text { Koch }\end{array}$ & $\begin{array}{l}\alpha \text {-pinene }{ }^{\mathrm{T}} ; \beta \text {-pinene } \\
\text { Tineole }\end{array}$ & $\begin{array}{l}\text { bees: Euglossa cyanura } \\
\quad \text { (Euglossini) }\end{array}$ & $\begin{array}{l}\text { Croat, 1980; } \\
\text { Whitten et al., } \\
\text { 1988; } \\
\text { Kuanprasert } \\
\text { et al., } 1998\end{array}$ \\
\hline $\begin{array}{l}\text { Anthurium sagittatum } \\
\text { (Sims) G. Don } \\
\text { (= A. rubrinervium } \\
\text { (Link) G. Don) }\end{array}$ & 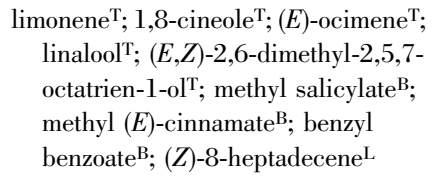 & $\begin{array}{l}\text { bees: Aglae caerulea, Euglossa } \\
\text { piliventris, Euglossa viridis } \\
\text { (Euglossini) }\end{array}$ & $\begin{array}{l}\text { Hentrich et al., } \\
2007,2010\end{array}$ \\
\hline $\begin{array}{l}\text { Anthurium salvadorense } \\
\text { Croat }\end{array}$ & $\begin{array}{l}\text { isobutyl acetate }{ }^{\mathrm{L}} \text {; isoamyl acetate }{ }^{\mathrm{L}} ; \\
\text { 6-methyl-5-hepten-2-yl acetate }\end{array}$ & flies: Drosophilidae & $\begin{array}{r}\text { Schwerdtfeger } \\
\text { et al., } 2002\end{array}$ \\
\hline $\begin{array}{l}\text { Spathiphyllum cannifolium } \\
\text { (Dryand. ex Sims) Schott } \\
\text { (cited as "S. } \\
\text { cannaefolium") }\end{array}$ & $\begin{array}{l}\text { limonene }^{\mathrm{T}} ; 1,8-\text { cineole }^{\mathrm{T}} \text {; benzyl } \\
\text { acetate }^{\mathrm{B}} ; \text { methyl eugenol }^{\mathrm{B}} ; \\
\text { eugenol }^{\mathrm{B}} \text {; methoxybenzyl } \text { alcohol }^{\mathrm{B}} \text {; } \\
\text { 4-methoxybenzyl acetate }{ }^{\mathrm{B}} ; 3,4- \\
\text { dimethoxybenzyl alcohol }^{\mathrm{B}} ; \\
\text { methylchavicol }^{\mathrm{P}} \text {; trans-3,4- } \\
\text { dimethoxycinnamyl alcohol }^{\mathrm{P}} \text {; trans- } \\
\text { 3,4-dimethoxycinnamyl acetate } \\
\text { isopropyl tetradecanoate }\end{array}$ & $\begin{array}{l}\text { bees: Eufriesea pulchra, } \\
\text { Eufriesea purpurata, } \\
\text { Euglossa analis, Euglossa } \\
\text { cordata, Euglossa cybelia, } \\
\text { Euglossa tridentata, } \\
\text { Euglossa variabilis, } \\
\text { Euglossa viridis, Eulaema } \\
\text { cingulata, Eulaema nigrita, } \\
\text { Exaerete smaragdina } \\
\text { (Euglossini) }\end{array}$ & $\begin{array}{l}\text { Ducke, 1902; } \\
\text { Vogel, 1963, } \\
\text { 1966; Williams } \\
\text { \& Dressler, } \\
\text { 1976; Lewis } \\
\text { et al., 1988; } \\
\text { Gerlach \& } \\
\text { Schill, 1991; } \\
\text { Chuah et al., } \\
\text { 1996; } \\
\text { Schwerdtfeger } \\
\text { et al., 2002; Tan } \\
\text { \& Nishida, 2012 }\end{array}$ \\
\hline $\begin{array}{l}\text { Spathiphyllum } \\
\text { cochlearispathum } \\
\text { (Liebm.) Engl. }\end{array}$ & $\begin{array}{l}(E, E)-\alpha \text {-farnesene }{ }^{\mathrm{T}} ;(E)-\alpha \text {-farnesene } \\
\quad \text { epoxide }^{\mathrm{T}} ; \text { methyl benzoate }{ }^{\mathrm{B}} ; \text { methyl } \\
\text { salicylate }^{\mathrm{B}} ; \text { phenylacetonitrile }\end{array}$ & $\begin{array}{l}\text { bees: Apis mellifera (Apini), } \\
\text { Plebeia sp. (Meliponini), } \\
\text { Euglossa viridissima } \\
\text { (Euglossini) }\end{array}$ & $\begin{array}{l}\text { Díaz Jiménez, } \\
2016\end{array}$ \\
\hline
\end{tabular}


Table 2. Continued.

\begin{tabular}{|c|c|c|c|}
\hline Species & Main compounds of floral scent* & $\begin{array}{l}\text { Pollinator species } \\
\text { (family or tribe) }\end{array}$ & References \\
\hline $\begin{array}{l}\text { Spathiphyllum humboldtii } \\
\text { Schott }\end{array}$ & $\begin{array}{l}\text { myrcene }^{\mathrm{T}} ; 1,8 \text {-cineole } \\
\text { methylene-1,3,7-methyl-6- } \\
\text { epoxy myrcene }^{\mathrm{T}} \text {; ipsdienone }{ }^{\mathrm{T}} ; 6,7- \\
\text { ipsdienol }^{\mathrm{T}}\end{array}$ & $\begin{array}{l}\text { bees: Euglossa chalybeata, } \\
\text { Euglossa decorata, Euglossa } \\
\text { retroviridis, Euglossa } \\
\text { stilbonota, Euglossa } \\
\text { townsendi, Eulaema } \\
\text { bombiformis, Exaerete } \\
\text { smaragdina (Euglossini) }\end{array}$ & $\begin{array}{l}\text { Hentrich et al., } \\
2010\end{array}$ \\
\hline $\begin{array}{l}\text { Spathiphyllum ortgiesii } \\
\quad \text { Regel }\end{array}$ & 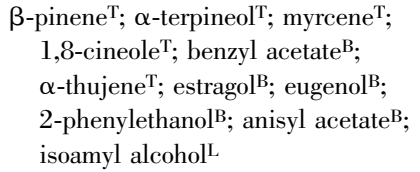 & $\begin{array}{l}\text { bees: Trigona fulviventris } \\
\quad \text { (Meliponini) }\end{array}$ & $\begin{array}{l}\text { Gerlach \& Schill, } \\
\text { 1991; Díaz } \\
\text { Jiménez, } 2016\end{array}$ \\
\hline
\end{tabular}

*Only volatile organic compounds (VOCs) reported as major compounds. T: terpenoid; B: benzenoid; P: phenylpropanoid; L: lipid-derived compound; N: nitrogen-containing compound; S: sulfur-containing compound.

Subsequently, the inflorescence enters in a male phase, which lasts two to three times longer than the female phase (Hentrich et al., 2010; Guevara-Ibarra, 2015). Generally, the stamens emerge from several flowers in a progressively acropetal sequence in two successive phases (i.e., first from the inner whorl, then the outer), increasing pollen availability. In rare cases, the anthers appear in different sections of the spadix (e.g., Anthurium lentii Croat \& R. A. Baker; Croat, 1980). In A. cotobrusii Croat \& R. A. Baker and A. hacumense Engl., scattered secretions on the tepals of different flowers were observed during the male phase (Croat, 1980). While the sexual phases are clearly separated in most species studied, a temporal overlap of the phases is also reported for a few others, suggesting possible selfpollination. In addition, there are some species that exhibit a dormant stage, which represents a neutral time interval between the end of the female phase and the start of the male phase (Croat, 1980; Beath, 1998; Franz, 2007). Thermogenesis has been studied in several species (including $A$. acaule (Jacq.) Schott, A. buganum Engl., A. cordifolium (Raf.) Kunth, A. digitatum (Jacq.) Schott, A. hookeri Kunth, A. pedatum (Kunth) Endl. ex Kunth, A. scandens, and A. truncicola Engl.), but heat production could not be determined in any of them (Leick, 1915; Guevara-Ibarra, 2015).

The floral odors are as diverse as the other floral traits. Definitive characterization and comparisons of scent across published data should be regarded with caution, as each author has his individual olfactory perception and different methods of fragrance detection. Furthermore, it should also be taken into account that environmental factors and the condition of the plant influence fragrance production (Knudsen \& Gershenzon, 2006). During anthesis (both female and male phases), the studied Anthurium species emitted odors that ranged from unpleasant (fishy or resembling rotten fruits) to agreeable (strongly minty or pine- or sweetscented) to the human nose. Nevertheless, there were also plants that did not smell at all to the authors (Kuanprasert \& Kuehnle, 1999; Schwerdtfeger et al., 2002). Floral scent emissions were detected at different times of the day and for different periods, depending on the species. The majority of species were mainly fragrant in the morning (e.g., A. acutifolium, A. apaporanum R. E. Schult., A armeniense, A. formosum Schott, and $A$. roseospadix Croat), while others smelled during the entire day (e.g., A. lindenianum K. Koch \& Augustin, A. moonenii Croat \& E. G. Gonç., misidentified as A. thrinax Madison; Hentrich et al., 2010) or even during the entire day and night (e.g., A. ochranthum) (Croat, 1980; Beath, 1998; Kuanprasert et al., 1998; Etl et al., 2017). Some species start scent emission later in the morning or only in the middle of the day, including A. sagittatum (9:00 hr. until dusk; Hentrich et al., 2010), A. hacumense (10:00-13:00 hr.; Beath, 1998), and A. fragrantissimum Croat (noon; Croat, 1980; Kuanprasert et al., 1998; Kuanprasert \& Kuehnle, 1999). The VOCs that have been reported belong to a broad variety of chemical groups, such as terpenoids (monoterpenes, sesquiterpenes), benzenoids, carotenoidderived compounds, lipid-derived compounds, and even nitrogen-containing compounds (Whitten et al., 1988; Kuanprasert et al., 1998; Schwerdtfeger et al., 2002; Hentrich et al., 2007, 2010; Etl et al., 2017) (Table 2).

Although there is the possibility of self-pollination or apomixis in some species (e.g., Anthurium scandens; Valerio \& Villalobos, 1980), most studies document geitonogamy or xenogamy as the standard within the genus. Among the variety of floral visitors that might act as pollinators of Anthurium, there are different kinds of bees (Apini, Augochlorini, Euglossini, Halictini, 
Meliponini, Tapinotaspidini), beetles (Curculionidae), and flies (Cecidomyiidae, Drosophilidae) (Ducke, 1902; Zucchi et al., 1969; Williams \& Dressler, 1976; Madison, 1979; Croat, 1980; van Dulmen, 2001; Schwerdtfeger et al., 2002; Franz \& Valente, 2005; Franz, 2007; Hentrich et al., 2010; Guevara-Ibarra, 2015; Etl et al., 2017; Ruiz-Idarraga, 2017). Other visitors, such as lepidopterans (Lepidotera), thrips (Thysanoptera), and even hummingbirds are mentioned as pollinators, but their role remains to be studied in more comprehensive investigations (Kraemer \& Schmitt, 1999; Gómez-Murillo \& Cuartas-Hernández, 2016; Hartley et al., 2017). In A. scandens, Valerio and Villalobos (1980) reported that no floral odor was detectable and that pollination occurred in the total absence of pollinators in experiments conducted under laboratory conditions. In situ pollination experiments with this species also support autogamy or apomixis, even though we could perceive a distinct, pleasant, sweet floral odor that could be an indication for pollinator attraction and thus a mixed mating system (Díaz Jiménez et al., unpublished data). Other species with self-pollination capabilities include: A. acaule, A. fendleri Schott, A. longistamineum Engl., A. salvinii Hemsl. (cited as "A. salviniae"), A. spectabile Schott, and A. obtusum (Engl.) Grayum (misapplied as A. trinerve Miq.), reviewed in Chouteau et al. (2006b, 2008). Unfortunately, visitor observations and descriptions of floral aromas are undocumented in some of the presumed autogamous species (Chouteau et al., 2006b) so that we cannot safely determine whether they are obligatory autogamous or have mixed mating systems. Mixed mating systems possibly exist in A. crystallinum Linden \& André, A. schlechtendalii Kunth, and A. upalaense Croat \& R. A. Baker, where autogamy and pollinators have been documented (Williams \& Dressler, 1976; Schwerdtfeger et al., 2002; Chouteau et al., 2006b, 2008; Franz, 2007).

\section{Other genera in Pothoideae}

Based on the morphology of the spadix in Pothos L., Hymenoptera are plausible pollinators of the genus (Yadav, 1998). Information is absent for the other two monotypic genera in the subfamily, Pedicellarum M. Hotta and Pothoidium Schott.

SUBFAMILY MONSTEROIDEAE

\section{Spathiphyllum}

Spathiphyllum is a terrestrial genus (Mayo et al., 1997) comprising 49 species, of which more than 90\% are restricted to the Neotropics (Cardona, 2004; Boyce \& Croat, 2018), while the rest are known to occur in Africa, Asia, and Melanesia (Zuluaga et al., 2015). The inflorescence is located on an erect peduncle; the spathe is frequently upright, white in most species but greenish and leaflike in others (Fig. 2D). In most species with a white spathe, the spathe ages to a greenish color (Bunting, 1960; Bown, 2000). Spathiphyllum has white or yellow-cream flowers distributed along a cylindrical spadix. Each flower has an ovoid, obovoid, or subcylindric pistil that exceeds the tepals (Mayo et al., 1997; Cardona, 2004).

Similarly to Anthurium, the flowering sequence of Spathiphyllum is quite variable and seems to be strongly species-specific. The information published so far includes durations between seven to 43 days (Montalvo \& Ackerman, 1986; Hentrich et al., 2010; Díaz Jiménez, 2016). Flowering begins with a female phase, where all stigmas are receptive at once and show a wet appearance, and proceeds with a male phase, which is usually clearly separated (anthers open after all stigmas have wilted) (Montalvo \& Ackerman, 1986; Hentrich et al., 2010). Depending on the species, the female phase can last between one to 13 days and the male phase between three to 30 days. A progressive and acropetal emergence of the anthers is the most frequently observed pattern in the male phase (Montalvo \& Ackerman, 1986; Hentrich et al., 2010). Spathiphyllum grandifolium Engl. is the only known exception, where many anthers emerge simultaneously in a basipetal pattern (Díaz Jiménez et al., unpublished data) and both phases overlap for several days, suggesting autogamy.

As in the previously discussed genera, the emission of VOCs plays an important role in the pollination of Spathiphyllum (Williams \& Dressler, 1976; Montalvo \& Ackerman, 1986; Gerlach \& Schill, 1991; Hentrich et al., 2010). In most species, the emission of a strong and pleasant floral perfume (e.g., lavender, honey, soap, sweet) has been reported in both sexual phases of anthesis, particularly during the morning hours (Williams \& Dressler, 1976; Montalvo \& Ackerman, 1986; Beath, 1998; Hentrich et al., 2010). The main VOCs identified are terpenoids (myrcene, ipsdienol) and aromatic benzenoids (benzyl acetate, eugenol, methyl benzoate, and methyl salicylate), all known as potent attractants of male euglossine bees (Gerlach \& Schill, 1991; Hentrich et al., 2010). There are no studies suggesting thermogenesis in the genus.

Most Spathiphyllum species studied have been shown to be pollinated by male orchid bees (Euglossini) or pollen-collecting bees (Apini, Meliponini) (Vogel, 1963, 1966; Williams \& Dressler, 1976; Montalvo \& Ackerman, 1986; Beath, 1998; Hentrich et al., 2010; Díaz Jiménez, 2016). Additionally, flies (Tephritidae) are reported as frequent visitors of $S$. cannifolium (Dryand. ex Sims) Schott (Lewis et al., 1988; Chuah et al., 1996; Tan \& Nishida, 2012), although their role as true pollinators is still doubtful. Spathiphyllum grandifolium is the only species that has been proposed to be autonomously autogamous since sexual phases 
overlapped and no floral visitors were observed (Díaz Jiménez et al., unpublished data). Although $S$. humboldtii Schott is pollinated by male orchid bees, another study assumed that it might be apomictic (Hentrich et al., 2010), while $S$. friedrichsthalii Schott, S. patinii (R. Hogg) N. E. Br., and S. wallisii Regel have been shown to be unable to reproduce in the absence of pollinators (i.e., there is a clear separation of the different sexual phases of all flowers of the spadix, and flowers decay when not pollinated; Chouteau et al., 2008).

\section{Monstera}

The Neotropical genus Monstera is hemiepiphytic and comprises about 38 species (Tam et al., 2004; Boyce \& Croat, 2018). The inflorescence of most species is located on an erect peduncle, except for the pendent one of M. tuberculata Lundell (Madison, 1977) (Fig. 2E). The developing spathe is green and turns yellowcream or pink during anthesis. It is tightly wrapped around the usually yellow-cream subcylindrical spadix, exceeding it in length. The thickened spadix bears flowers with four stamens but without a perianth (Madison, 1979; Mayo et al., 1997). The lowermost flowers are usually sterile (Chouteau et al., 2007, 2009; Prieto \& Cascante-Marín, 2017).

Most studied Monstera species exhibit a flowering sequence that lasts about five days (e.g., M. adansonii Schott, M. deliciosa Liebm., and M. lentii Croat \& Grayum) (Chouteau et al., 2007, 2009; Prieto \& Cascante-Marín, 2017). In M. obliqua Miq., this sequence lasts for only 48 hours but is distributed over three days, with an intermediate, dormant phase of up to 14 hours (Chouteau et al., 2007). In all four species, the flowering pattern is identical, with a female phase longer than the male phase. Depending on the species, the female phase lasts 28 to 72 hours while the male phase lasts two to 48 hours. The spathe is tightly folded around the spadix before flowering begins. At the onset of the female phase, all stigmas of the inflorescence are receptive at the same time, and the spathe unfolds slightly, creating a floral chamber that is only accessible through a small opening. After the second or third day, the female phase ends and all anthers of the spadix mature at once, releasing pollen (Chouteau et al., 2007, 2009). Meanwhile, the chamber remains more or less closed until the end of the male phase, when it eventually opens. In contrast to $M$. lentii and $M$. obliqua, the lowermost sterile flowers of M. acuminata K. Koch, M. adansonii, and M. deliciosa release a resin before shedding large amounts of pollen (Chouteau et al., 2007, 2009; Díaz Jiménez, pers. obs.). Generally, the spathe falls off two to three days after flowering (Madison, 1977).

The inflorescences of all studied Monstera species emit a sweet or bittersweet odor, mostly noticeable between morning and noon in both phases of anthesis (Chouteau et al., 2007, 2009; Prieto \& Cascante-Marín, 2017), but the floral scent composition has never been determined. Thermogenesis is common in the genus, with the spadix temperature rising a few degrees, $0.5^{\circ} \mathrm{C}-2.5^{\circ} \mathrm{C}$ higher than the ambient air, between the beginning of the female phase to the beginning of the male phase. Subsequently, the temperature rises even more, reaching $2^{\circ} \mathrm{C}-5^{\circ} \mathrm{C}$ above the ambient air during anther dehiscence (Chouteau et al., 2007, 2009; Prieto \& Cascante-Marín, 2017).

The pollinators recorded for Monstera (e.g., M. lentii, M. obliqua) are mainly small beetles (Nitidulidae), while the role of flies (Drosophilidae) in pollination of $M$. lentii is still discussed (Chouteau et al., 2007; Prieto \& CascanteMarín, 2017). Self-pollination has only been reported for M. lentii, although with only a $10 \%$ average fruit-set per inflorescence (Prieto \& Cascante-Marín, 2017).

\section{Other genera in Monsteroideae}

Heteropsis integerrima (Vell.) Stellfeld is visited by bees and small hemipterans, but these insects have not been confirmed as pollinators (Madison, 1979). In Rhaphidophora Hassk., distinct species from Asia and $R$. africana N. E. Br. from Africa are apparently pollinated by different insect groups. In $R$. decursiva (Roxb.) Schott and R. hookeri Schott, fruit flies (Colocasiomyia) use the inflorescences as a breeding site during most of their life cycle, feeding on floral exudates and/or solid substances produced by the stamens, not pollen grains (Sultana et al., 2006; Toda \& Lakim, 2011; Fartyal et al., 2013; Li et al., 2014; Gibernau, 2016). Similar observations of Colocasiomyia species are reported for Epipremnum pinnatum (L.) Engl. and Scindapsus coriaceus Engl. (Sultana et al., 2006; Fartyal et al., 2013; Li et al., 2014). On the other hand, in $R$. pertusa (Roxb.) Schott, Hymenoptera are mentioned as possible pollinators (Yadav, 1998). Raphidophora africana bears a white spadix that emits a sweet odor during a short two-day anthesis. Beath (1993) documented that this species, besides being capable of selfpollination, might be pollinated by diurnal beetles (Hoplia) that feed on stigmatic secretions in the female phase and on pollen in the male phase. Stenospermation Schott inflorescences are mentioned to be visited infrequently and in low numbers by flies (Gómez-Murillo \& Cuartas-Hernández, 2016), but further studies are needed to adequately assess pollination systems within this species-rich genus.

For all other genera within the subfamily (i.e., Alloschemone Schott, Amydrium Schott, Anadendrum Schott, Holochlamys Engl., and Rhodospatha Poepp.) information on their pollination ecology is completely absent. 
SUBFAMILY LASIOIDEAE

\section{Anaphyllopsis}

The genus Anaphyllopsis is terrestrial and comprises three species distributed in tropical South America (Mayo et al., 1997). Anaphyllopsis americana (Engl.) A. Hay is the only species whose pollination has been studied (Barabé \& Lacroix, 2008; Gibernau et al., $2010 \mathrm{~b})$. The inflorescence is located on a very long erect peduncle. The lanceolate spathe is up to six times longer than the spadix, convolute basally, forming a sort of chamber around the spadix, and spirally twisted apically (Hay, 1988) (Fig. 2F). Spathe color varies from pale greenish to reddish brown on the outside and creamy white with purple margins on the inside toward the base (Hay, 1988) (Fig. 2F, G). The small, purplish to creamy white, subcylindric spadix has tetramerous or pentamerous flowers (Barabé \& Lacroix, 2008).

Gibernau et al. (2010b) documented that the flowering sequence of Anaphyllopsis americana lasts about 40 days. When the spathe opens, the female phase begins, and all stigmas become receptive at the same time. This phase lasts 14 to 22 days. Subsequently, all anthers of a few basal flowers mature. During the next 17 to 24 days, more anthers open in a basipetal pattern (Barabé \& Lacroix, 2008; Gibernau et al., 2010b). The spadix emits a faint, rose-like scent (Boos, 1997), but its chemical composition is still undetermined. During the entire flowering time, the spadix heats up slightly and reaches temperatures that are $2^{\circ} \mathrm{C}-3^{\circ} \mathrm{C}$ higher than those of the ambient air (Gibernau et al., 2010b).

It was shown that Anaphyllopsis americana is neither autogamous nor apomictic. Thus, its reproduction relies entirely on cross-pollination. However, no definite pollinators could be assigned to this species yet. A generalist pollination system has been suggested (Chouteau et al., 2006a; Gibernau et al., 2010b).

\section{Other genera in Lasioideae}

The inflorescences of Dracontioides Engl. and Dracontium emit a rotting meat-like odor. In these two genera and in Lasia Lour., unidentified flies have been observed on the inflorescences, and pollination by deceit could be present (e.g., mimicking an oviposition site), as found in the genus Arum L. (Croat, 1975; Boos, 1997; Gibernau et al., 2004; Zhu \& Croat, 2004; Gonçalves, 2005; Bröderbauer et al., 2012; Flores et al., 2016). Finally, Lasimorpha senegalensis Schott (cited as Cyrtosperma senegalense (Schott) Engl.) is visited by nitidulid beetles, which have not been confirmed as pollinators (Knecht, 1983).

Information is absent for the remaining genera in the subfamily (i.e., Anaphyllum Schott, Cyrtosperma, Podolasia N. E. Br., Pycnospatha Thorel ex Gagnep., and Urospatha Schott).
SUBFAMILY AROIDEAE (POSSIBLY)

\section{Calla}

Calla is a monotypic genus (Mayo et al., 1997) with its terrestrial species $C$. palustris L. growing in streams and ponds, and presenting a circumboreal distribution. The inflorescence is located on a long erect peduncle, with the spathe (elliptic or ovate-lanceolate) completely expanded, persistent, and white at anthesis (Mayo et al., 1997) (Fig. $2 \mathrm{H})$. Its cylindrical spadix comprises white, bisexual flowers (Lehman \& Sattler, 1992; Ulrich et al., 2013) and at the top a group of flowers with exclusively nonfunctional stamens (Chartier et al., 2017).

The flowering sequence begins with the total opening of the spathe and with the stigmas becoming receptive in an acropetal pattern on the spadix (Chartier et al., 2017). This phase lasts two to five days. Generally, one to two days after the end of the female phase, the male phase starts with the emergence of several stamens per day in an acropetal pattern. In some individuals studied, the phases overlapped for one or two days, suggesting possible self-pollination. The inflorescences apparently do not produce heat, and no floral odor could be detected by the human nose.

Flies (Syrphidae) and beetles (Chrysomelidae, Nitidulidae) have been considered potential pollinators of Calla palustris (Thompson, 2000; Chartier et al., 2017). Besides this, the species is capable of self-pollination or apomixis, with approximately $16 \%$ of autogamous/ apomictic fruits per inflorescence (Chartier et al., 2017). Therefore, C. pallustris also seems to have a mixed mating system.

\section{Poluination Types in Aroids with Bisexual Flowers}

Although the morphological structure of the inflorescences is roughly the same in all aroids with bisexual flowers, there is significant variation in shape, color, size, and scent, as well as in the groups of pollinators associated with them. Grayum (1990) and Mayo et al. (1997) proposed that beetles and flies are generally the most common pollinators among Araceae. Our review of the available data showed that bees are probably the third most frequent pollinator group among the bisexual-flowered members of the family, particularly in many species of the large genus Anthurium and possibly in most species of Spathiphyllum. In the following sections, we list all reported pollination vectors found in bisexual-flowered aroids and note their associated floral characteristics.

\section{WIND POLLINATION}

Grayum (1986) once proposed that wind pollination might be the ancestral pollination mode in Araceae, but 
extant Araceae species do not present floral features typically related to wind pollination (e.g., no pendant anthers, no anthers exposed to the wind, and when there is a lot of pollen produced, it is sticky). Moreover, low population densities and large distances between flowering plants render wind pollination rather unlikely (Camazine \& Niklas, 1984; H. Hentrich, pers. obs.). If it happens in Araceae, wind pollination is probably "accidental" or partial and so far has never been shown to be the main pollination mode for any species. However, it is often proposed to explain fruit-set for species where pollinators are very scarce. In taxa that grow in larger clumps, such as Anthurium and Spathiphyllum, "accidental" wind pollination between different clones or several inflorescences of the same plant might occur, and fruits could set if no genetic incompatibility mechanisms are present. Camazine and Niklas (1984) suggested that wind pollination is possible in Symplocarpus foetidus, owing to the asymmetrical opening of the spathe and the airflow generated around the spadix. However, due to the small or non-existent amount of pollen transported by the wind between different inflorescences, the wind apparently is not a primary pollen vector in this genus (Thorington, 2000). Wind pollination has also been discussed as an alternative pollination mode in Lysichiton camtschatcensis and Calla palustris, but this is unlikely in these taxa (Tanaka, 2004; Chartier et al., 2017). Many of the suggested cases of wind pollination lack in situ observations and remain to be tested.

\section{BEETLE POLLINATION}

Beetle pollination in aroids with bisexual flowers has been reported for Anthurium, Calla, Lysichiton, Monstera, and Symplocarpus (Pellmyr \& Patt, 1986; Uemura et al., 1993; Willson \& Hennon, 1997; Chouteau et al., 2007; Franz, 2007; Brousil et al., 2015; Chartier et al., 2017; Prieto \& Cascante-Marín, 2017; Brodie et al., 2018). The plants whose inflorescences produce floral chambers offer shelter, heat, a mating site, and food as rewards and are pollinated by Staphylinidae (rove beetles) and Nitidulidae (sap beetles) (Uemura et al., 1993; Chouteau et al., 2007; Prieto \& Cascante-Marín, 2017). Chrysomelidae (leaf beetles), Curculionidae (weevils), and also Nitidulidae and Staphylinidae have been reported as pollinators in some genera that have exposed inflorescences without a floral chamber and that are not thermogenic (Pellmyr \& Patt, 1986; Willson \& Hennon, 1997; Franz \& Valente, 2005; Franz, 2007; Brousil et al., 2015; Chartier et al., 2017; Brodie et al., 2018). The pollinators predominantly visit these plants for courtship and to feed on pollen and floral tissues. Weevils additionally lay eggs on the inflorescences (Franz, 2007; Chartier et al., 2017; Ruiz-Idarraga, 2017).
The taxon that has been studied most comprehensively is Lysichiton americanus. This species is pollinated by Pelecomalium testaceum beetles (Staphylinidae) and is unusual among all beetle-pollinated aroids for lacking a pollination chamber and thermogenesis (Pellmyr \& Patt, 1986; Willson \& Hennon, 1997; Brousil et al., 2015). Instead of a chamber, the insects use the space between spathe and spadix to congregate (Pellmyr \& Patt, 1986; Willson \& Hennon, 1997; Brousil et al., 2015). Both male and female beetles are specifically attracted to the flowers by three floral scent compounds, (E)-4-nonene and (E)-5undecene, both lipid-derived compounds, and indole. Indole is the VOC responsible for the odor that is perceived by humans as carrion- or feces-like. Interestingly, the two lipid-derived compounds are not signature odorants of carrion or feces. Instead, they are assumed to be a particular signal to the beetles for plant recognition related to the rewards (i.e., pollen and mating site) (Pellmyr \& Patt, 1986; Brodie et al., 2018). Additionally, these beetles are also apparently attracted by the yellow spathe color (Pellmyr \& Patt, 1986; Willson \& Hennon, 1997; Brousil et al., 2015).

Unlike the previous species, Symplocarpus and Monstera are thermogenic and form a "true" floral chamber (Mayo et al., 1997; Seymour \& Blaylock, 1999; Chouteau et al., 2007, 2009; Seymour et al., 2009). In S. renifolius, staphylinid beetles are reported as possible pollinators (Uemura et al., 1993), but the pollination mechanism is poorly documented. The beetles are probably attracted by the floral heat and the unpleasant aroma and receive shelter and/or pollen as rewards (Uemura et al., 1993).

Some species of the genus Monstera are pollinated by small nitidulid beetles. The floral sequence of the plants is adapted to their visits and the spadix is thermogenic (e.g., M. lentii, M. obliqua) (Chouteau et al., 2007, 2009; Prieto \& Cascante-Marín, 2017). Depending on the Monstera species, the beetles arrive at the inflorescences early in the morning, at noon or in the afternoon, when the sweet or bittersweet odor is emitted (Chouteau et al., 2007; Prieto \& Cascante-Marín, 2017). They enter the floral chamber during the female phase through the slit of the spread spathe or through a hole in the apex where the spathe is twined, and remain inside the chamber until the end of the anthesis (Chouteau et al., 2007; Prieto \& Cascante-Marín, 2017). When the spathe opens completely at the end of the male phase, the beetles leave the inflorescence with pollen stuck to their bodies. Monstera offers different types of rewards to the beetles, such as shelter, a mating (and possibly breeding) site, and large amounts of pollen (Chouteau et al., 2007; Prieto \& Cascante-Marín, 2017). The sterile, basal flowers of $M$. adansonii and $M$. deliciosa produce a resin that is supposed to play a role as additional food for the pollinators (Ramírez \& 
Gómez, 1978; Chouteau et al., 2009). Heat production in Monstera species increases at the end of the male phase (Chouteau et al., 2007, 2009; Prieto \& CascanteMarín, 2017) and could generally act as an energy reward for pollinators as proposed by Chouteau et al. (2007) for M. obliqua. Considering the flowering pattern, duration of flowering, the presence of a pollination chamber, and the rewards received, the pollination system of Monstera is very similar to the one reported for aroids with unisexual flowers and kettle traps pollinated by scarab beetles (Dynastinae) (Seymour et al., 2003; Seymour \& Gibernau, 2008; Gibernau, 2016).

Nitidulid, as well as chrysomelid beetles, are reported as possible pollinators of Calla palustris, another taxon that does not form a pollination chamber. Unfortunately, information about the pollination of this species is still scarce (Chartier et al., 2017), but either pollen or stigmatic secretions might be the rewards offered to the pollinators.

In various Anthurium species, Cyclanthura flowerweevils have been observed as floral visitors (Franz \& Valente, 2005; Franz, 2007; Guevara-Ibarra, 2015; Ruiz-Idarraga, 2017). Generally, weevils appear to be an underestimated pollinator group. They are mostly documented to damage the inflorescence, thus their pollinator status is controversial (Guevara-Ibarra, 2015; Gibernau, 2016; Ruiz-Idarraga, 2017). However, several studies revealed their importance in the pollination of Cyclanthaceae and Arecaceae (Gottsberger, 1991; Dhileepan, 1992; Eriksson, 1994; Franz, 2004; Barfod et al., 2011). Cyclanthura beetles are known to be highly specific visitors and probably important pollinators of several Cyclanthaceae species, using the inflorescences as a breeding site (Franz, 2004; Franz \& Valente, 2005). Franz (2007) proposed different Cyclanthura species as pollinators of A. consobrinum Schott, A. formosum, A. cf. gualeanum Engl., A. tilaranense Standl., and A. upalaense. The beetles are apparently attracted by the pleasant floral aroma emitted by these plants, and visited inflorescences in small numbers during the female and male phases of anthesis to copulate, oviposit, consuming plant tissues and/or pollen (Franz \& Valente, 2005; Franz, 2007).

However, Guevara-Ibarra (2015) and Ruiz-Idarraga (2017) showed, in more comprehensive studies, that the weevils visiting Anthurium buganum and A. kunthii Poepp. were herbivores that contributed little to the pollination of the plants. These beetles visited the inflorescences before or during flowering. They ate floral tissue and pollen, copulated, and laid their eggs on the inflorescences. The larvae fed on the inflorescence axis, causing death to some or all flowers. The authors also observed that flowers that were damaged in pre-anthesis did not present a female phase. Instead, only a few anthers in different parts of the spadix emerged. This "phase jump" has also been observed in other Anthurium species where inflorescences in pre-anthesis were manually damaged, simulating a possible attack by herbivores (Díaz Jiménez et al., unpublished data).

\section{FLY POLLINATION}

Based on our current knowledge, flies are one of the most frequently observed groups of anthophilous visitors associated with pollination in Araceae (Gibernau, 2016). However, they are frequently noted as additional visitors, besides other insect groups, which have been identified as true pollinators. Since most fly-visitors are very small and difficult to observe, it is often unclear which role they play in the pollination of the plants. They generally visit aroid inflorescences in search of food rewards, courtship, and oviposition substrate, but according to the aroid species visited they obtain the reward (mutualism) or not (deception) (Chartier et al., 2014).

Nevertheless, the information available to date, mainly from the genera Anthurium, Lysichiton, and Symplocarpus, even though not well documented, still gives us an idea about the importance of fly pollination in aroid genera with bisexual flowers. The most common flies visiting bisexual flowers belong to the family Drosophilidae (fruit flies), which seem to primarily visit the inflorescences to mate and oviposit. Flowers pollinated by these flies usually emit a scent that resembles fermented or ripe fruit, dominated by lipid-derived compounds, which are supposed to be attractive for them (Croat, 1980; Schwerdtfeger et al., 2002). On the other hand, flower color seems to be less specific and varies from white to green or dark red.

Anthurium hookeri and A. salvadorense Croat have been reported to be pollinated by species of the genus Drosophila (Schwerdtfeger et al., 2002), while six other Anthurium species are also assumed to be pollinated by Drosophilidae (Croat, 1980; Schwerdtfeger et al., 2002). These authors mention that the behavior of the fruit flies is similar to that shown in the deposition of eggs in rotten fruits. Nevertheless, the deposition of fly eggs on Anthurium inflorescences has never been observed. Since it is assumed that the insects are not rewarded with nutrients or substrate for their larvae by these plants, the pollination system resembles the deceptive pollination of inflorescences with kettle traps, but without trapping the pollinators (Gibernau, 2016). In A. lucens Standl. and A. verapazense Engl., fruit flies were observed to copulate and to lick tiny secretions found over the tepals (Díaz Jiménez, pers. obs.).

Drosophilidae are also considered potential pollinators of Monstera lentii. Their flower visits are similar to those already described for beetles in this species. They possibly use the inflorescences as a breeding site (Prieto 
\& Cascante-Marín, 2017). The floral scent in Monstera is sweet or bittersweet, different from Anthurium species mentioned in the previous paragraph (Schwerdtfeger et al., 2002; Prieto \& Cascante-Marín, 2017). In the genera Epipremnum Schott, Rhaphidophora, and Scindapsus Schott, Drosophilidae (Colocasiomyia species) are only documented as visitors, although the possibility that they may also be pollinators is not precluded. The flies use the inflorescences as a breeding site during most of their life cycle, additionally feeding on floral exudates and/or solid substances (but no pollen) produced by the stamens (Sultana et al., 2006; Toda \& Lakim, 2011; Fartyal et al., 2013). Symplocarpus renifolius is the only species where Drosophilidae visited the flowers to exclusively feed on pollen. However, their role as pollinators of this species is doubtful (Hong \& Sohn, 2003).

The use of the inflorescence as a breeding site by flies is a mode of pollination that shares many similarities with the traits associated with beetle pollination (e.g., some components of the scent and color patterns) (Endress, 1994; Dobson, 2006; Willmer, 2011). It has been shown that pollinator selection exerts tremendous selective pressure in aroids, as evidenced by numerous cases of convergence toward particular groups of insect visitors even from distantly related taxa (Chartier et al., 2014). Interestingly, Drosophilidae are also reported as pollinators of different taxa with unisexual flowers that belong to the late-diverging Aroideae subfamily (e.g., Alocasia (Schott) G. Don, Colocasia Schott, Homalomena Schott). It has been comprehensively documented that in these cases, they also use the inflorescences as a breeding site (Carson \& Okada, 1980; Yafuso, 1993; Miyake \& Yafuso, 2003, 2005; Takano et al., 2012; Yafuso et al., 2015). Such convergence of the drosophilid-aroid interaction in different clades of Araceae should be further studied in order to better understand the evolution of pollinator-plant interactions. Possibly, fly pollination was derived from beetle pollination in this plant family (Grayum, 1985, 1986, 1990; Chartier et al., 2014). Nevertheless, ancestral reconstruction of pollination mode is still difficult in the family due to the small percentage of species for which pollination has been studied in detail.

Spathiphyllum cannifolium, a species native to northern South America, was frequently used as a "flytrap" in Asian orchards to reduce infestations of fruiting trees by different species of Tephritidae (e.g., Bactrocera carambolae, B. papayae), another group of fruit flies (Lewis et al., 1988; Chuah et al., 1996). Methyl eugenol, one of the major floral scent compounds of the plant, is highly attractive to males of these flies (Lewis et al., 1988; Chuah et al., 1996), who lick the floral tissues to convert methyl eugenol into pheromones that attract the females (Nishida et al., 2004; Tan \& Nishida, 2012). However, their role as pollinators of this species has not been determined yet. In South America, the principal pollinators of $S$. cannifolium are clearly euglossine bees (Vogel, 1963; Williams \& Dressler, 1976).

The second large group of flies visiting bisexualflowered Araceae are Cecidomyiidae (gall midges). They are mentioned as possible pollinators of some Anthurium species, whose inflorescences they use as a mating site during the night, apparently attracted by specific scents that are imperceptible to humans (Schwerdtfeger et al., 2002). Cecidomyiidae are earlydiverging flies, which are generally assumed to be poor pollinators (Willemstein, 1987; Willmer, 2011). However, several studies have documented that they successfully pollinate different species of other plant families such as Artocarpus integer (Thunb.) Merr. (Moraceae), Piper novae-hollandiae Miq. (Piperaceae), and Siparuna Aubl. species (Monimiaceae). In these plants, the flies are attracted by pleasant floral perfume and use the inflorescences as a breeding site (Feil, 1992; Ollerton, 1996; Sakai et al., 2000).

Inflorescences of Symplocarpus renifolius are also visited by several additional fly groups (i.e., Anthomyiidae, Fanniidae, Lauxaniidae, Simuliidae) that are considered their pollinators. These flies are supposed to predominantly visit the flowers to feed on pollen and are possibly attracted by the heat produced by the spadix and/or the unpleasant floral odor (Uemura et al., 1993; Hong \& Sohn, 2003). In S. foetidus, Nemouridae (stoneflies) are considered the true pollinators of the plants since they are the only frequent visitors that carried pollen on their bodies and landed on inflorescences during both sexual phases (Thorington, 2000). Unfortunately, the colloquial name of these insects is somewhat misleading since they actually do not belong to the order Diptera, but represent a separate order, Plecoptera. Stoneflies are mainly distributed in the Northern Hemisphere and feed mostly on detritus (Baumann, 1975), although adults of many species sometimes also consume pollen and nectar and generally use flowers to mate (Willemstein, 1987; Sato \& Kato, 2017). However, in S. foetidus, they have never been observed feeding on any nutritional reward. They are possibly attracted by the unpleasant odor of the inflorescence, which in S. foetidus is dominated by dimethyl disulphide, and are assumed to use the floral chamber, which is heated up by thermogenesis, as shelter (Thorington, 2000; Kozen, 2013).

Anthomyiidae and Lauxaniidae flies, possibly attracted by the floral scent, have also been observed as visitors of Lysichiton camtschatcensis, but the type of reward could not be determined (Tanaka, 2004). Unidentified species of flies have also been reported as visitors in Calla palustris. They are possibly attracted by the color of the spathe and feed either on pollen or on stigmatic secretions. However, in both plant species, 
their role as pollinators is still unclear (Tanaka, 2004; Chartier et al., 2017).

\section{BEE POLLINATION}

After beetles and flies, bees are the third most frequently documented pollinator group in Araceae with bisexual flowers. Remarkably, Anthurium, one of the most species-rich genera within Araceae, and in particular Spathiphyllum are supposed to be largely pollinated by bees (Williams \& Dressler, 1976; Montalvo \& Ackerman, 1986; Beath, 1998; Schwerdtfeger et al., 2002; Hentrich et al., 2010; Díaz Jiménez, 2016; Etl et al., 2017). On the other hand, in the unisexualflowered Aroideae, bee pollination is rather an exception. It is only known from Arum creticum Boiss. \& Heldr. (Diaz \& Kite, 2006), but mentioned as a possible pollination type in Anchomanes Schott and some Amorphophallus Blume ex Decne. species (Gibernau, 2003, 2011).

Among the bee pollinators of Anthurium and Spathiphyllum reported so far are species of Apini (honey bees), Augochlorini (halictine bees), Euglossini (orchid bees), Halictini (halictine bees), Meliponini (stingless bees), and Tapinotaspidini. The flowers pollinated by these bees share certain characteristics, such as a diurnal anthesis and a pleasant floral scent, which is primarily emitted in the morning hours in both sexual phases and acts as the main attractant (Williams \& Dressler, 1976; Montalvo \& Ackerman, 1986; GuevaraIbarra, 2015; Díaz Jiménez, 2016; Etl et al., 2017). However, they differ in the type of reward they offer. Male euglossine and Tapinotaspidini bees gather floral scents (Williams \& Dressler, 1976; Schwerdtfeger et al., 2002; Hentrich et al., 2010; Etl et al., 2017), while the remaining bee groups visit the flowers to feed on pollen or stigmatic secretions, or to collect pollen for their offspring (Williams \& Dressler, 1976; Montalvo \& Ackerman, 1986; Beath, 1998; Guevara-Ibarra, 2015; Díaz Jiménez, 2016; Ruiz-Idarraga, 2017).

Araceae species that are pollinated by male euglossine bees have only been found so far in the genera Anthurium and Spathiphyllum (Williams \& Dressler, 1976; Gerlach \& Schill, 1991; Schwerdtfeger et al., 2002). Flower color and shape seem to play a minor role in the attraction of these bees (Ramírez et al., 2002; Dötterl \& Vereecken, 2010). Male euglossine bees visit flowers in both sexual phases in search of floral scent and pollinate them by performing a scent-collecting behavior during the visits (Dressler, 1967; Ramírez et al., 2002; Hentrich et al., 2010). They apply fatty acids produced by their mandibular glands to the flower surface. The VOCs accumulate in the oil and are subsequently wiped up with the tarsal brushes of their forelegs (Hentrich et al., 2010). In this way, pollen grains stick to the long hairs of the foretarsi in malephase inflorescences (Hentrich et al., 2010) and get transferred to the wet stigmas when this behavior is repeated in flowers in the female phase. During flight, the bees transfer the oil to invaginations on their enlarged hind tibiae, where the VOCs are stored (Roubik \& Hanson, 2004).

The floral fragrances are mostly composed of a set of terpenoids and benzenoids, with a few compounds dominating the bouquet, which is the same in the female and male phases of the inflorescence of a given species (Gerlach \& Schill, 1991; Kuanprasert et al., 1998; Schwerdtfeger et al., 2002; Hentrich et al., 2010). It is assumed that the composition of the floral scent determines the bee species attracted (e.g., Dodson, 1970; Williams \& Dodson, 1972). Hentrich et al. (2010) showed that the attraction of euglossine pollinators in the sympatric species Anthurium sagittatum, A. thrinax, and Spathiphyllum humboldtii is highly specific and that there is no overlap in the main pollinating species. In a summary of their fieldwork, Williams and Dressler (1976) listed many different euglossine visitors of Anthurium and Spathiphyllum inflorescences. They recapitulated that only very few bee species, a maximum of three, dominated the visits quantitatively. Therefore, the authors of both studies assume that the composition of the specific floral scent of each plant species might be important for the reproductive isolation and sympatric occurrence of certain Anthurium and Spathiphyllum species (Williams \& Dressler, 1976; Hentrich et al., 2010).

A new specialized pollination system similar to pollination by male euglossine bees has recently been discovered in Anthurium acutifolium (Etl et al., 2017). Male Paratetrapedia chocoensis bees (Tapinotaspidini) were attracted by the floral scent emitted by the inflorescence during the mornings. The bees brushed the surface of the inflorescence in both sexual phases and in doing so pollinated the flowers in a mechanism similar to that of male euglossine-pollinated aroids. Instead of using their legs, tapinotaspid bees collected the scent compounds with the lower side of their densely hairy abdomen. The hairs were previously soaked with oil collected from other sources. It was assumed that the VOCs of A. acutifolium were the only floral rewards for the bees.

Honeybees, stingless bees, and halictine bees, which collect pollen on male-phase inflorescences, have been reported as pollinators of various Anthurium and Spathiphyllum species (Montalvo \& Ackerman, 1986; Beath, 1998; Guevara-Ibarra, 2015; Díaz Jiménez, 2016; Ruiz-Idarraga, 2017). In the collection process, the bees brush the tepals and anthers of the flowers in the male-phase inflorescences with their forelegs (Díaz Jiménez, 2016). Afterward, they store the pollen in the 
scopae of their hind tibiae during flight. Stingless bees also open anthers with their mandibles and eat the pollen directly (Díaz Jiménez, 2016). In the only two comprehensive studies to date, the authors observed that flowers were pollinated when the bees visited functionally female inflorescences by mistake (Montalvo \& Ackerman, 1986; Díaz Jiménez, 2016). These inflorescences had the same scent composition and the same appearance as functionally male ones (Montalvo \& Ackerman, 1986; Díaz Jiménez, 2016). After landing on female-phase inflorescences, the bees stayed for a few seconds and then flew away. Apparently, they did not receive any reward at the flowers (Guevara-Ibarra, 2015). Some pollen grains from flowers visited in the male phase remained on their bodies and were transferred to the wet stigmas when they crawled over the female-phase spadix. It might be that intraspecific sexual mimicry occurs in these plants (i.e., inflorescences in female phase mimicking the male phase) as known from several dioecious plants (Willmer, 2011). In Anthurium caucavallense Croat and A. kunthii, flowers in female phase produce sweet stigmatic exudates, which may serve as reward for the bees (RuizIdarraga, 2017). Furthermore, Beath (1998) mentions that in Spathiphyllum phryniifolium Schott and Trigona fulviventris (Meliponini) bees collect wax from the conical styles in the female phase but change their behavior in male-phase inflorescences, where they collect pollen. However, further research is needed to get a clearer understanding of the complete pollination process.

In contrast to plants of the subfamily Aroideae, the pollen of bisexually flowered, bee-pollinated taxa is starchless and apparently lipid-rich. Some authors assume that this could be a pre-adaptation of these genera to attract pollen-collecting bees (Baker \& Baker, 1979; Grayum, 1985). Conversely, pollen of some Spathiphyllum and Anthurium species is mixed with calcium oxalate raphides, which is supposed to be a protection against pollen robbers (Gerlach \& Schill, 1991; Barabé et al., 2004). However, not all species of Anthurium and Spathiphyllum produce these crystals (Coté \& Gibernau, 2012). For example, in S. cochlearispathum (Liebm.) Engl. and S. ortgiesii Regel, which are pollinated by pollen-collecting bees, calcium oxalate raphides mixed with pollen were not found (Díaz Jiménez, 2016). Therefore, the assumption that the pollen is adapted to pollen-collecting bees might be valid only for some species.

Stingless bees have also been described as floral visitors of different Monstera species (e.g., M. deliciosa, M. lentii), consuming pollen and stigmatic exudates (Ramírez \& Gómez, 1978; Prieto \& Cascante-Marín, 2017). Since the inflorescences in this genus are almost closed during the female phase and bees have only been observed at opened inflorescences at the end of flowering, we assume that the bees should be disregarded as pollinators, at least in the cases studied more thoroughly (Chouteau et al., 2007; Prieto \& CascanteMarín, 2017).

During visits, stingless bees and honeybees sometimes display an aggressive behavior. They appear to defend "their" spadix from other visitors by chasing them, pushing them away, or landing on them with widely opened legs. In this way, they prevent other potential pollinators from landing on the flowers and even drive them away (H. Hentrich, pers. obs.).

Stingless bees have the reputation of being pollen predators and therefore apparently contribute little to the pollination of most plants. This is probably one of the reasons why their potential as pollinators is sometimes ignored in aroid pollination studies. However, the observations of Montalvo and Ackerman (1986) showed that they were efficient pollinators in Spathiphyllum friedrichsthalii. We therefore believe that stingless bees pollinate significantly more species than currently assumed and that their role as pollinators should be more intensively studied in the near future.

There are also observations of Anthurium and Spathiphyllum species, where pollination by male euglossine bees and pollen-collecting bees coincide (Montalvo \& Ackerman, 1986; Guevara-Ibarra, 2015; Díaz Jiménez, 2016). In these cases, the pollination impact and efficiency of both bee groups are different and often depend on factors such as habitat and growth habit of the plants, among others. For plants that do not offer floral resources in the female phase, pollination by pollen-collecting bees presumably works best if these plants grow in larger populations (e.g., S. friedrichsthalii, S. cochlearispathum). Due to the high number of individuals ( = large amount of pollen), the bees stay in a population for a long time and visit a vast number of inflorescences in one place. Thus, the probability of accidently visiting flowers in the female phase is higher (Montalvo \& Ackerman, 1986; Díaz Jiménez, 2016). The disadvantage of this behavior is that outcrossing occurs mostly between plants of the same population. In contrast, euglossine bees are considered to do traplining, following the same specific foraging route every day and crossing large distances (Janzen, 1971; Roubik \& Hanson, 2004). They usually visit only a few plants in a population and continue their flight through the forest. By visiting different sites, euglossine bees are assumed to contribute to "long-distance" gene flow between populations (Armbruster \& Webster, 1979; Armbruster et al., 1989). The foraging behavior of euglossine bees is especially important in bisexual-flowered aroid species that grow scattered in low density in the forest and do not offer floral resources during the female phase. Flowering individuals are often widely separated and mistakepollination by pollen-collecting bees is probably less 
efficient than the specific visits by euglossine bees (Montalvo \& Ackerman, 1986; Díaz Jiménez, 2016).

\section{Discussion}

Araceae present unique and diverse inflorescences that have evolved elaborated pollination-related traits, including thermogenesis, a variety of scents, different types of rewards, and even floral chambers (Gibernau et al., 2010a; Bröderbauer et al., 2012; Chartier et al., 2014; Gibernau, 2016). Although they appear to bear less sophisticated inflorescences than the unisexualflowered Aroideae, five subfamilies of Araceae with bisexual flowers (not considering Lemnoideae) have evolved toward a great and puzzling variety of pollination mechanisms (Chartier et al., 2014; Gibernau, 2016).

It is tempting to expect genera with bisexual flowers and no floral chamber to be generalists from a pollination point of view since the inflorescence is exposed for long periods (up to seven weeks) and does not present a particularly obvious way of excluding certain visitors (Gibernau et al., 2010a; Bröderbauer et al., 2012). However, this case is rare considering the number of species whose pollination has been studied (Uemura et al., 1993; Hong \& Sohn, 2003; Gibernau et al., $2010 \mathrm{~b})$. The publications reviewed here document that some species show a high degree of specialization, being pollinated by one or only a few insect species. Besides beetle- and fly-pollinated taxa, bee-pollinated species seem to be more common than originally expected. Current data suggest that the group of bisexual-flowered aroids is probably more diverse in its pollinator spectrum than the unisexual-flowered Aroideae. This is not surprising since the group consists of several clades (i.e., six subfamilies) each of which was independently able to develop adaptations to different pollinator groups (Cusimano et al., 2011; Chartier et al., 2014).

An important factor for pollination in Araceae, if not the major one, is the floral scent chemistry. In Aroideae, it has been shown that the composition of floral VOCs and the exact timing of their emission are decisive for the specific attraction of their pollinators and successful pollination (Chartier et al., 2011; Dötterl et al., 2012; Gottsberger et al., 2013; Maia et al., 2013; Hoe et al., 2016). The few published studies in bisexual-flowered aroids that combine the observation of floral visitors and the analysis of floral scent give the impression that pollinator specificity in this group is to a large extent also related to their floral scent. It is assumed that certain categories of scent compounds account for the attraction of distinct pollinator groups (Schwerdtfeger et al., 2002; Etl et al., 2017). At least in species pollinated by male euglossine bees, scent composition does not only determine the pollinator group, but often even the pollinating species (Schwerdtfeger et al., 2002; Hentrich et al., 2010). In species pollinated by flies, beetles, and pollen-collecting bees, we know that scent is at least specific for the pollinator group (Schwerdtfeger et al., 2002; Díaz Jiménez, 2016). Future studies will show if the attraction is also species-specific in these pollination systems.

We suppose that there is a high selective pressure on the composition of floral scent in aroids with bisexual flowers since the open inflorescence structure gives very few possibilities to restrict visitor access. For species pollinated by male euglossine bees, floral scent serves as a reproductive barrier between sympatric species, leading to the attraction of different groups or specific species of pollinators (Hentrich et al., 2010). Since the sympatric distribution of congeneric species is a common phenomenon in aroids with bisexual flowers, it is feasible that floral scent is generally of importance for their reproductive isolation (Williams \& Dressler, 1976; Schwerdtfeger et al., 2002).

Besides the sexuality of the flowers, the most noticeable morphological difference between uni- and bisexual aroids is the spathe. In the Aroideae, it often encloses the spadix, creating a pollination chamber (Mayo et al., 1997; Gibernau, 2003). With the exception of some genera in the subfamily Monsteroideae, the entire spathe in aroids with bisexual flowers is always open, mostly standing below, behind, or above the spadix (Grayum, 1990; Mayo et al., 1997; Bröderbauer et al., 2012). Quite rarely it is bowl-shaped around the spadix. The open spathe might be another reason for the greater pollinator diversity in this group. Its plasticity (and to some extent the spadix's plasticity) allows the plant to evolve morphological features to adapt to different pollinators (Bröderbauer et al., 2012; Chartier et al., 2014).

In our opinion, the great variability of spathe and spadix shapes and colors reflects the many different pollinators that, for the most part, have not yet been studied. In many species, the spathe is conspicuously colored, or additionally emits scents, probably playing a role as visual and olfactory attractant (Pellmyr \& Patt, 1986; Kevan, 1989; Kraemer \& Schmitt, 1999; Zhu \& Croat, 2004; Brodie et al., 2018). Spathe shape might be of importance for attraction as well. In several genera of the Rhaphidophora clade (Epipremnum, Monstera, Rhaphidophora, Scindapsus; sensu Cusimano et al., 2011; Fig. 1), the inflorescence mimics the Aroideae kettle traps and enables these plants to have almost the same pollination mechanism and similar pollinator groups as in Aroideae (Sultana et al., 2006; Chouteau et al., 2007; Toda \& Lakim, 2011; Fartyal et al., 2013; Jameson \& Drumont, 2013; Gibernau, 2016; Prieto \& CascanteMarín, 2017). Maybe the spathe also serves to concentrate sunlight to the center of the inflorescence (i.e., the 
spadix) and to slightly raise the temperature there, which helps insects to heat up and which facilitates the emission of floral volatiles, especially in species belonging to the two temperate genera Lysichiton and Symplocarpus. In the cases where the spathe stands above the inflorescence, it might serve as an umbrella (e.g., Anthurium pedatum), supporting pollination during rainy days, to some extent (Madison, 1979; Schwerdtfeger et al., 2002). Nevertheless, there are also species in which the spathe is small and inconspicuous and appears to have only a minor role, if any, in the pollination process.

In Aroideae, heat production is presumably related to the kettle-trap mechanism and the mostly nocturnal flowering, with associated lower temperatures. The heating process can take place in a single or two consecutive events (e.g., Taccarum Brongn. ex Schott and Philodendron, respectively) (Maia et al., 2010, 2013). For the taxa presenting only one event, heating occurs in the female phase (Maia et al., 2013). In the more frequent "two-peaks" pattern, the temperature rises first at the beginning of the female phase and then again at the dehiscence of the anthers (Seymour et al., 2003; Maia et al., 2010; Gottsberger et al., 2013). The first increase enhances the volatilization of the floral perfume, which ensures the exactly timed arrival of the pollinators in a short flowering sequence (Gibernau, 2003). The second increase stimulates physiological processes to assure a rapid pollen shedding and serves as an energy boost for the pollinators when leaving the inflorescences (Seymour et al., 2003).

In the bisexual-flowered aroids, heat production has only been documented in taxa that produce kettle traps or whose spadix is wrapped by the spathe. These include the Neotropical genera Anaphyllopsis and Monstera and the temperate genus Symplocarpus (Uemura et al., 1993; Chouteau et al., 2009; Gibernau et al., 2010b). Although the floral ecology of other bisexual-flowered genera with kettle traps (i.e., Epipremnum, Monstera, Rhaphidophora, Scindapsus) has not been studied yet, it is feasible that floral thermogenesis is equally related to the morphology of their inflorescence as in Aroideae. Nevertheless, in the Neotropical genera studied so far, the temperature increase was not as pronounced as in the Aroideae taxa, which brings into question the significance of thermogenesis in these plants (Chouteau et al., 2007, 2009; Gibernau et al., 2010b; Prieto \& Cascante-Marín, 2017). In Monstera, the spadix temperature was almost the same as the ambient daytime temperature. Significant differences were only measured during the night or in the early morning (Chouteau et al., 2007, 2009; Prieto \& Cascante-Marín, 2017). Temperatures peaked in the early morning of the last day of flowering, when pollen was shed, and the spathe opened to release the beetles. Therefore, the authors argue that the heat might serve to aid in pollen shedding and to increase the beetles' body heat. In Anaphyllopsis thermogenesis seems to be very rudimentarily expressed, with a spadix temperature that is only marginally higher than that of the surrounding air (Gibernau et al., 2010b). Since our knowledge about the pollination of this genus is generally very poor, further interpretation is currently not possible.

The prevailing absence of floral thermogenesis in the bisexual-flowered taxa is sometimes explained by the fact that most of these plants are distributed in the tropics and flower during daytime. It might be that the warmer climate conditions had an impact on the evolution of heat production (thermogenesis). For tropical taxa, daytime temperatures are high enough to volatilize the scent. Furthermore, the arrival and departure of floral visitors and the release of pollen in taxa that do not produce a floral chamber do not require the precise timing observed in the Aroideae. The sexual phases usually take several days, during which the visitors come and go over a longer period while the anthers gradually mature (Croat, 1980). Keeping inflorescences warm for the entire flowering sequence could easily prove to be energetically costly and inefficient. Moreover, ambient temperatures are high enough for the visitors to be active. In fact, the problem for them would more likely be overheating during peak solar irradiance from 11:00 to 17:00 hr. The occurrence of a clearly pronounced thermogenesis in the temperate genus Symplocarpus, which flowers in early spring during cold weather (Uemura et al., 1993; Seymour, 2004), supports this hypothesis. Chouteau et al. (2009) suggested that the heating in Symplocarpus may be necessary to enable the plant to mature the anthers and to release the pollen when ambient temperatures drop below zero. Moreover, it has been shown that the spadix heating around $23^{\circ} \mathrm{C}$ corresponds to the temperature optimum for pollen germination on the stigma (Seymour et al., 2009). Additionally, the heat increases the volatilization of the floral VOCs and the pollinators might benefit from the warm shelter.

Another remarkable difference between aroids with unisexual and bisexual flowers is the flowering phenology and its duration, which have also probably evolved in conjunction with flower sexuality and spathe shape. While the flowering of an inflorescence in Aroideae is very short (a few days) and the exact timing of flower maturation is precisely harmonized (Gibernau, 2003), the inflorescences in the other subfamilies last for several days to weeks (except for some genera in Monsteroideae, e.g., Rhaphidophora, Monstera), and the timing does not appear to be equally precise (Beath, 1993; Chouteau et al., 2007). Also, the flowering process within an inflorescence is different (Croat, 1980; Montalvo \& Ackerman, 1986; Gibernau et al., 2010b). 
In Aroideae, all flowers of the same sex open at once, whereas this is only the case for the female phase in most species with bisexual flowers. For the male phase, we find a different flowering pattern, where the simultaneous maturation of all flowers of the spadix is an exception rather than the rule. Most species display a progressive acropetal maturation, where the stamens of different whorls are exposed one after another over a long period of time (Croat, 1980; Hentrich et al., 2010). The short flowering and simultaneous maturation of flowers in the Aroideae are obviously related to the kettle-trap pollination mechanism (Gibernau, 2003; Bröderbauer et al., 2012; Chartier et al., 2014). Since the pollinators are trapped in the floral chamber, a longer flowering time would probably result in the death of most insects. Simultaneous maturation of the flowers and precise harmonization are inevitable, since the pollinators leave the inflorescence as soon as they are released. The opening of the anthers must take place quickly to ensure that pollen is shed on the insects before they have left the inflorescence (Bröderbauer et al., 2012). Accordingly, the bisexual-flowered genera of the Rhaphidophora clade, which also produce pollination chambers, have fewer flowering days and a completely different maturation pattern than the other taxa. Here, all flowers in the female phase and subsequently in the male phase mature at once (Beath, 1993; Chouteau et al., 2007; Prieto \& Cascante-Marín, 2017).

Most other species that produce open inflorescences do not have the possibility of forcing their visitors to remain in a floral chamber, where they would invariably come into contact with the stigmas and pollinate most flowers. These aroids are also unable to enforce pollen transfer by shedding pollen on the visitors when passing at the only exit of the inflorescence. Therefore, open inflorescences depend on repeated and steady visits of the pollinators, and, in most plants, the same visitors probably visit the same inflorescence during the female and male phases, which are often several days apart. In order to accomplish a high reproductive success, flowering time has to necessarily be extended and the plant must ensure that attractants and floral resources are continuously produced from the beginning until the end of flowering.

Interestingly, all species with bisexual flowers studied so far (except in Monstera) share a female phase that lasts considerably less than the male one, resulting in many more functionally male inflorescences in relation to female ones flowering at any given time in a population (Hentrich et al., 2010; Gibernau et al., 2010b). Montalvo and Ackerman (1986) assumed that the lengthier male phase in Spathiphyllum friedrichsthalii is the result of mistake-pollination by stingless bees. As the bees do not receive any reward at functionally female flowers, higher frequencies of inflorescences in the female phase would increase the number of unrewarded visitation events and could eventually hinder further visits. Therefore, natural selection might favor a longer-lasting male phase. This hypothesis makes sense for stingless bee pollination in $S$. friedrichsthalii and could also prove to be true for other plants pollinated by stingless bees or by other pollenforaging insects. However, there are many species that are visited for rewards other than pollen (e.g., floral scent in male euglossine-pollinated plants), which nonetheless present the same ratio of female to malephase inflorescences in natural populations. In general, higher pollen availability is typical for many dioecious, monoecious, and dichogamous plants (Proctor et al., 1996). It might be that the male phase dominates temporally because this increases the probability that a floral visitor would carry pollen when landing on an inflorescence in the female phase. The reverse flowering strategy would probably result in less pollen circulating and lower pollination rates.

\section{Conctusions}

We would like to stress that pollination systems are unknown in more than half of the aroid genera with bisexual flowers, and especially in Old World species. For many pollination systems, information is scarce and spread over multiple anecdotic, sometimes contradictory, reports. For some others, attempts to identify pollinators have had little success (e.g., Uemura et al., 1993; Gibernau et al., 2010b; Chartier et al., 2017), and many aspects of their reproductive biology remain a mystery. It is necessary to confirm anecdotic reports regarding the putative pollinators of many species, especially in some genera that do not fit well in the characteristics attributed to a particular subset of pollinators and that might be novel among the known pollination modes (e.g., hummingbird pollination in Anthurium; Kraemer \& Schmitt, 1999). Studying the remaining genera thus offers a very promising field of research, as much for the understanding of the evolution of the Araceae family as for the possible discovery of types of interactions so far undocumented in angiosperms.

\section{Literature Cited}

Armbruster, W. S. \& G. L. Webster. 1979. Pollination of two species of Dalechampia (Euphorbiaceae) in Mexico by euglossine bees. Biotropica 11: 278-283.

Armbruster, W. S., S. Keller, M. Matsuki \& T. P. Clausen. 1989. Pollination of Dalechampia magnoliifolia (Euphorbiaceae) by male euglossine bees. Amer. J. Bot. 76: 1279-1285.

Baker, H. G. \& I. Baker. 1979. Starch in angiosperm pollen grains and its evolutionary significance. Amer. J. Bot. 66: 591-600. 
Barabé, D. \& C. Lacroix. 2008. Developmental morphology of the flower of Anaphyllopsis americana and its relevance to our understanding of basal Araceae. Botany 86: 1467-1473.

Barabé, D., C. Lacroix, M. Chouteau \& M. Gibernau. 2004. On the presence of extracellular calcium oxalate crystals on the inflorescences of Araceae. Bot. J. Linn. Soc. 146: 181-190.

Barfod, A. S., M. Hagen \& F. Borchsenius. 2011. Twenty-five years of progress in understanding pollination mechanisms in palms (Arecaceae). Ann. Bot. 108: 1503-1516.

Baumann, R. W. 1975. Revision of the stonefly family Nemouridae (Plecoptera): A study of the world fauna at the generic level. Smithsonian Contr. Zool. 211: 1-74.

Beath, D. N. 1993. Biology of Forest Araceae in Ghana. Ph.D. Dissertation, University of Aberdeen, Aberdeen.

Beath, D. N. 1998. Pollination ecology of the Araceae. <http:// www.aroid.org/pollination/beath/index.php $>$, accessed 8 September 2017.

Boos, J. O. 1997. Observations on New World AraceaeLasieae. Aroideana 20: 13-26.

Bown, D. 2000. Aroids: Plants of the Arum Family, ed. 2. Timber Press, Portland.

Boyce, P. C. \& T. B. Croat. 2018. The Überlist of Araceae, totals for published and estimated number of species in aroid genera. <http://www.aroid.org/genera/18021luberlist. pdf $>$, accessed 29 October 2018.

Bröderbauer, D., A. Diaz \& A. Weber. 2012. Reconstructing the origin and elaboration of insect-trapping inflorescences in the Araceae. Amer. J. Bot. 99: 1666-1679.

Brodie, B. S., A. Renyard, R. Gries, H. Zhai, S. Ogilvie, J. Avery \& G. Gries. 2018. Identification and field testing of floral odorants that attract the rove beetle Pelecomalium testaceum (Mannerheim) to skunk cabbage, Lysichiton americanus (L.). Arthropod-Pl. Interact. 12: 591-599.

Brousil, M., C. Humann \& D. Fischer. 2015. Plant-pollinator interactions in a Northwest arum related to plant traits but not riparian forest management. Northwest Sci. 89: 297-307.

Bunting, G. S. 1960. A revision of Spathiphyllum (Araceae). Mem. New York Bot. Gard. 10: 1-54.

Cabrera, L. I., G. A. Salazar, M. W. Chase, S. J. Mayo, J. Bogner \& P. Dàvila. 2008. Phylogenetic relationships of aroids and duckweeds (Araceae) inferred from coding and noncoding plastid DNA. Amer. J. Bot. 95: 1153-1165.

Camazine, S. \& K. J. Niklas. 1984. Aerobiology of Symplocarpus foetidus: Interactions between the spathe and spadix. Amer. J. Bot. 71: 843-850.

Cardona, F. 2004. Synopsis of the genus Spathiphyllum (Araceae) in Colombia. Ann. Missouri Bot. Gard. 91: 448-456.

Carson, H. L. \& T. Okada. 1980. Drosophilidae associated with flowers in Papua New Guinea. I. Colocasia esculenta. Kontyu 48: 15-29.

Chartier, M., P. Pélozuelo \& M. Gibernau. 2011. Do floral odor profiles geographically vary with the degree of specificity for pollinators? Investigation in two sapromyophilous Arum species (Araceae). Ann. Soc. Entomol. France 47: 71-77.

Chartier, M., M. Gibernau \& S. S. Renner. 2014. The evolution of pollinator-plant interaction types in the Araceae. Evolution 68: 1533-1543.

Chartier, M., J. L. Fernandez, D. Prehsler, J. Schönenberger $\&$ M. Gibernau. 2017. Note on the pollination of Calla palustris L. (Araceae). Aroideana 40: 71-83.

Chouteau, M., D. Barabé \& M. Gibernau. 2006a. Pollen-ovule ratios in some Neotropical Araceae and their putative significance. Pl. Syst. Evol. 257: 147-157.

Chouteau, M., D. Barabé \& M. Gibernau. 2006b. A comparative study of inflorescence characters and pollen-ovule ratios among the genera Philodendron and Anthurium (Araceae). Int. J. Pl. Sci. 167: 817-829.

Chouteau, M., M. McClure \& M. Gibernau. 2007. Pollination ecology of Monstera obliqua (Araceae) in French Guiana. J. Trop. Ecol. 23: 607-610.

Chouteau, M., M. Gibernau \& D. Barabé. 2008. Relationships between floral characters, pollination mechanisms, life forms, and habitats in Araceae. Bot. J. Linn. Soc. 156: 29-42.

Chouteau, M., D. Barabé \& M. Gibernau. 2009. Flowering and thermogenetic cycles in two species of Monstera (Araceae). Bull. Soc. Hist. Nat. Toulouse 145: 5-10.

Chuah, C. H., L. E. Ooi, H. S. Yong \& S. H. Goh. 1996. New male fruitfly attractants from spadix of Spathiphyllum cannaefolium (Araceae). Biochem. Syst. Ecol. 24: 189-193.

Coté, G. G. \& M. Gibernau. 2012. Distribution of calcium oxalate crystals in floral organs of Araceae in relation to pollination strategy. Amer. J. Bot. 99: 1231-1242.

Croat, T. B. 1975. A new species of Dracontium (Araceae) from Panama with notes on the sapromyophilous pollination syndrome. Selbyana 1: 168-171.

Croat, T. B. 1980. Flowering behavior of the Neotropical genus Anthurium (Araceae). Amer. J. Bot. 67: 888-904.

Croat, T. B. 1983. A revision of the genus Anthurium (Araceae) of Mexico and Central America. Part I: Mexico and Middle America. Ann. Missouri Bot. Gard. 70: 211-420.

Croat, T. B. 1988. Ecology and life forms of Araceae. Aroideana 11: 4-55.

Croat, T. B. 1998. Tropical aroids: Taxonomy, diversity and ecology. Pp. 235-286 in P. Mathew \& M. Sivadasan (editors), Diversity and Taxonomy of Tropical Flowering Plants. Mentor Books, Calicut.

Cusimano, N., J. Bogner, S. J. Mayo, P. C. Boyce, S. Y. Wong, M. Hesse, W. L. A. Hetterscheid, et al. 2011. Relationships within the Araceae: Comparison of morphological patterns with molecular phylogenies. Amer. J. Bot. 98: 1-15.

Dhileepan, K. 1992. Pollen carrying capacity, pollen load and pollen transferring ability of the oil palm pollinating weevil Elaeidobius kamerunicus Faust in India. Oleagineux 47: $55-61$.

Diaz, A. \& G. C. Kite. 2006. Why be a rewarding trap? The evolution of floral rewards in Arum (Araceae), a genus characterized by saprophilous pollination systems. Biol. J. Linn. Soc. 88: 257-268.

Díaz Jiménez, P. 2016. Biología Floral y Reproductiva de Spathiphyllum cochlearispathum (Liebm.) Engl. y Spathiphyllum ortgiesii Regel (Araceae) en la Región de Los Tuxtlas, Veracruz, México. Master's thesis, Universidad Veracruzana, Xalapa.

Dobson, H. E. M. 2006. Relationship between floral fragrance composition and type of pollinator. Pp. 147-198 in N. Dudareva \& E. Pichersky (editors), Biology of Floral Scent. Taylor \& Francis, Boca Raton.

Dodson, C. H. 1970. The role of chemical attractants in orchid pollination. Pp. 83-107 in K. L. Chambers (editor), Biochemical Coevolution. Oregon State University Press, Corvallis.

Dötterl, S. \& N. J. Vereecken. 2010. The chemical ecology and evolution of bee-flower interactions: A review and perspectives. Canad. J. Zool. 88: 668-697.

Dötterl, S., A. David, W. Boland, I. Silberbauer-Gottsberger \& G. Gottsberger. 2012. Evidence for behavioral attractiveness of methoxylated aromatics in a dynastid scarab beetlepollinated Araceae. J. Chem. Ecol. 38: 1539-1543.

Dressler, R. L. 1967. Why do euglossine bees visit orchid flowers? Pp. 171-188 in H. Lent (editor), Atas do Simpósio 
sóbre a Biota Amazônica, Vol. 5: Zoologia-. Conselho Nacional de Pesquisas, Rio de Janeiro.

Ducke, A. 1902. Beobachtungen über Blütenbesuch, Erscheinungszeit etc. der bei Pará vorkommenden Bienen. Allg. Z. Entomol. 7: 321-326.

Endress, P. K. 1994. Diversity and Evolutionary Biology of Tropical Flowers. Cambridge University Press, Cambridge.

Eriksson, R. 1994. The remarkable weevil pollination of the Neotropical Carludovicoideae (Cyclanthaceae). Pl. Syst. Evol. 189: 75-81.

Etl, F., A. Franschitz, A. J. C. Aguiar, J. Schönenberger \& S. Dötterl. 2017. A perfume-collecting male oil bee? Evidences of a novel pollination system involving Anthurium acutifolium (Araceae) and Paratetrapedia chocoensis (Apidae, Tapinotaspidini). Flora 232: 7-15.

Fartyal, R. S., J. J. Gao, M. J. Toda, Y.-G. Hu, K. T. Takano, A. Suwito, T. Katoh, et al. 2013. Colocasiomyia (Diptera: Drosophilidae) revised phylogenetically, with a new species group having peculiar lifecycles on monsteroid (Araceae) host plants. Syst. Entomol. 38: 763-782.

Feil, I. P. 1992. Reproductive ecology of dioecious Siparuna (Monimiaceae) in Ecuador: A case of gall midge pollination. Biol. J. Linn. Soc. 110: 171-203.

Flores, R., E. Campos-Pineda, M. D. Correa A. \& W. Adsett. 2016. First records of Calathea vinosa (Marantaceae) and Dracontium pittieri (Araceae) from Panama. Phytoneuron 51: 1-4.

Franz, N. M. 2004. Analysing the history of the derelomine flower weevil-Carludovica association (Coleoptera: Curculionidae; Cyclanthaceae). Biol. J. Linn. Soc. 81: 483-517.

Franz, N. M. 2007. Pollination of Anthurium (Araceae) by derelomine flower weevils (Coleoptera: Curculionidae). Int. J. Trop. Biol. 55: 269-277.

Franz, N. M. \& R. M. Valente. 2005. Evolutionary trends in derelomine flower weevils: From associations to homology. Invertebr. Syst. 19: 499-530.

Gerlach, G. \& R. Schill. 1991. Composition of orchid scents attracting euglossine bees. Bot. Acta 104: 379-391.

Gibernau, M. 2003. Pollinators and visitors of aroid inflorescences. Aroideana 26: 66-83.

Gibernau, M. 2011. Pollinators and visitors of aroid inflorescences: An addendum. Aroideana 34: 70-83.

Gibernau, M. 2016. Pollinators and visitors of aroid inflorescences III-Phylogenetic \& chemical insights. Aroideana 39: 4-22.

Gibernau, M., D. Macquart \& G. Przetak. 2004. Pollination in the genus Arum-A review. Aroideana 27: 148-166.

Gibernau, M., M. Chartier \& D. Barabé. 2010a. Recent advances toward an evolutionary comprehension of Araceae pollination. Pp. 101-114 in S. Ole, P. Gitten, B. Anders S. \& D. Jarrold I. (editors), Diversity, Phylogeny, and Evolution in the Monocotyledons. Aarhus University Press, Aarhus.

Gibernau, M., M. Chouteau, K. Lavallée \& D. Barabé. 2010b. Notes on the phenology, morphometry and floral biology of Anaphyllopsis americana (Araceae). Aroideana 33: 183-191.

Gómez-Murillo, L. \& S. Cuartas-Hernández. 2016. Patterns of diversity of flower visitor assemblages to the understory Araceae in a tropical mountain forest in Colombia. J. Insect Conserv. 20: 1069-1085.

Gonçalves, E. G. 2005. A revision of the genus Dracontioides Engl. (Araceae), including a new species from Bahia, Brazil. Aroideana 28: 21-31.

Gottsberger, G. 1991. Pollination of some species of Carludovicoideae, and remarks on the origin and evolution of Cyclanthaceae. Bot. Jahrb. Syst. 113: 221-235.
Gottsberger, G., I. Silberbauer-Gottsberger \& S. Dötterl. 2013. Pollination and floral scent differentiation in species of the Philodendron bipinnatifidum complex (Araceae). Pl. Syst. Evol. 299: 793-809.

Grayum, M. H. 1985. Evolutionary and ecological significance of starch storage in pollen of the Araceae. Amer. J. Bot. 72: 1565-1577.

Grayum, M. H. 1986. Correlations between pollination biology and pollen morphology in the Araceae, with some implications for angiosperm evolution. Pp. 313-327 in S. Blackmore \& I. K. Ferguson (editors), Pollen and Spores: Form and Function. Academic Press, London.

Grayum, M. H. 1990. Evolution and phylogeny of Araceae. Ann. Missouri Bot. Gard. 77: 628-697.

Guevara-Ibarra, L. 2015. Biología Reproductiva de Anthurium buganum (Araceae) en el Parque Natural Regional El Vínculo, Colombia. Undergraduate thesis, Universidad del Valle, Cali.

Hartley, N., T. Krömer \& M. Gibernau. 2017. Lepidopteran visitors of Anthurium inflorescences. Aroideana 40: 84-96.

Hay, A. 1988. Anaphyllopsis: A new Neotropical genus of Araceae-Lasieae. Aroideana 11: 25-31.

Hentrich, H., R. Kaiser \& G. Gottsberger. 2007. Floral scent collection at the perfume flowers of Anthurium rubrinervium (Araceae) by the kleptoparasitic orchid bee Aglae caerulea (Euglossini). Ecotropica 13: 149-155.

Hentrich, H., R. Kaiser \& G. Gottsberger. 2010. Floral biology and reproductive isolation by floral scent in three sympatric aroid species in French Guiana. Pl. Biol. 12: 587-596.

Hoe, Y. C., M. Gibernau, A. C. D. Maia \& S. Y. Wong. 2016. Flowering mechanisms, pollination strategies and floral scent analyses of sympatric co-flowering Homalomena spp. (Araceae) on Borneo. Pl. Biol. 18: 563-576.

Hong, S. P. \& J. C. Sohn. 2003. Pollination of Symplocarpus renifolius Schott ex Miquel (Araceae) in Korea. Korean J. Pl. Taxon. 33: 165-179.

Ito, K., T. Ito, Y. Onda \& M. Uemura. 2004. Temperaturetriggered periodical thermogenic oscillations in skunk cabbage (Symplocarpus foetidus). Pl. Cell Physiol. 45: 257-264.

Ito-Inaba, Y., Y. Hida \& T. Inaba. 2009a. What is critical for plant thermogenesis? Differences in mitochondrial activity and protein expression between thermogenic and nonthermogenic skunk cabbages. Planta 231: 121-130.

Ito-Inaba, Y., M. Sato, H. Masuko, Y. Hida, K. Toyooka, M. Watanabe \& T. Inaba. 2009b. Developmental changes and organelle biogenesis in the reproductive organs of thermogenic skunk cabbage (Symplocarpus renifolius). J. Exp. Bot. 60: 3909-3922.

Jameson, M. L. \& A. Drumont. 2013. Aroid scarabs in the genus Peltonotus Burmeister (Coleoptera, Scarabaeidae, Dynastinae): Key to species and new distributional data. ZooKeys 320: 63-95.

Janzen, D. H. 1971. Euglossine bees as long-distance pollinators of tropical plants. Science 171: 203-205.

Kevan, P. G. 1989. How honey bees forage for pollen at skunk cabbages, Symplocarpus foetidus (Araceae). Apidologie 20: 485-490.

Klotz, L. H. 1992. On the biology of Orontium aquaticum L. (Araceae), golden club or floating arum. Aroideana 15: 25-33.

Knecht, M. 1983. Aracées de Côte d'Ivoire. Contribution à l'étude biosystématique des représentants d'Aracées de la Côte d'Ivoire. Phanerog. Monogr., XVII. Cramer, Vaduz.

Knudsen, J. T. \& J. Gershenzon. 2006. The chemical diversity of floral scent. Pp. 27-52 in N. Dudareva \& E. Pichersky (editors), Biology of Floral Scent. Taylor \& Francis, Boca Raton. 
Knutson, R. M. 1972. Temperature measurements of the spadix of Symplocarpus foetidus (L.) Nutt. Amer. Midl. Naturalist 88: 251-254.

Knutson, R. M. 1979. Plants in heat. Nat. Hist. 88: 42-47.

Kozen, E. N. 2013. The Scent of Eastern Skunk Cabbage, Symplocarpus foetidus (Araceae): Qualification of Floral Volatiles and Sex Differences in Floral Scent Composition. Master's thesis, Indiana University of Pennsylvania, Indiana.

Kraemer, M. \& U. Schmitt. 1999. Possible pollination by hummingbirds in Anthurium sanguineum Engl. (Araceae). Pl. Syst. Evol. 217: 333-335.

Kuanprasert, N. \& A. R. Kuehnle. 1999. Fragrance quality, emission, and inheritance in Anthurium species and hybrids. Aroideana 22: 48-62.

Kuanprasert, N., A. R. Kuehnle \& C. S. Tang. 1998. Floral fragrance compounds of some Anthurium (Araceae) species and hybrids. Phytochemistry 49: 521-528.

Lee, S., S. Lee, K. Heo \& S.-C. Kim. 2010. Palynological insights of the eastern Asian and eastern North American disjunct genus Symplocarpus (Araceae). J. Pl. Res. 123: $723-729$.

Lehman, N. L. \& R. Sattler. 1992. Irregular floral development in Calla palustris (Araceae) and the concept of homeosis. Amer. J. Bot. 79: 1145-1157.

Leick, E. 1915. Die Erwärmungstypen der Araceen und ihre blütenbiologische Deutung. Ber. Deutsch. Bot. Ges. 33: $350-351$

Lewis, J. A., C. J. Moore, M. T. Fletcher, R. A. Drew \& W. Kitching. 1988. Volatile compounds from the flowers of Spathiphyllum cannaefolium. Phytochemistry 27: 2755-2757.

Li, N.-N., M. J. Toda, Z. Fu, J.-M. Chen, S.-H. Li \& J.-J. Gao. 2014. Taxonomy of the Colocasiomyia gigantea species group (Diptera, Drosophilidae), with descriptions of four new species from Yunnan, China. ZooKeys 406: 41-64.

Madison, M. 1977. A revision of Monstera (Araceae). Contr. Gray Herb. 207: 3-100.

Madison, M. 1979. Protection of developing seeds in Neotropical Araceae. Aroideana 2: 52-61.

Maia, A. C. D., C. Schlindwein, D. M. A. F. Navarro \& M. Gibernau. 2010. Pollination of Philodendron acutatum (Araceae) in the Atlantic Forest of Northeastern Brazil: A single scarab beetle species guarantees high fruit set. Int. J. Pl. Sci. 171: 740-748.

Maia, A. C. D., M. Gibernau, A. T. Carvalho, E. G. Gonçalves \& C. Schlindwein. 2013. The cowl does not make the monk: Scarab beetle pollination of the Neotropical aroid Taccarum ulei (Araceae, Spathicarpeae). Biol. J. Linn. Soc. 108: $22-34$.

Mayo, S. J., J. Bogner \& P. C. Boyce. 1997. The Genera of Araceae. Royal Botanic Gardens, Kew.

Miyake, T. \& M. Yafuso. 2003. Floral scents affect reproductive success in fly-pollinated Alocasia odora (Araceae). Amer. J. Bot. 90: 370-376.

Miyake, T. \& M. Yafuso. 2005. Pollination of Alocasia cucullata (Araceae) by two Colocasiomyia flies known to be specific pollinators for Alocasia odora. Pl. Spec. Biol. 20: 201-208.

Montalvo, A. M. \& J. D. Ackerman. 1986. Relative pollinator effectiveness and evolution of floral traits in Spathiphyllum friedrichsthalii (Araceae). Amer. J. Bot. 73: 1665-1676.

Moodie, G. E. E. 1976. Heat production and pollination in Araceae. Canad. J. Bot. 54: 545-546.

Nie, Z.-L., H. Sun, H. Li \& J. Wen. 2006. Intercontinental biogeography of subfamily Orontioideae (Symplocarpus,
Lysichiton, and Orontium) of Araceae in eastern Asia and North America. Molec. Phylogen. Evol. 40: 155-165.

Nishida, R., K.-H. Tan, S.-L. Wee, A. K.-W. Hee \& Y.-C. Toong. 2004. Phenylpropanoids in the fragrance of the fruit fly orchid, Bulbophyllum cheiri, and their relationship to the pollinator, Bactrocera papayae. Biochem. Syst. Ecol. 32: 245-252.

Ollerton, J. 1996. Interactions between gall midges (Diptera: Cecidomyiidae) and inflorescences of Piper novae-hollandiae (Piperaceae) in Australia. Entomologist 115: 181-184.

Pellmyr, O. \& J. M. Patt. 1986. Function of olfactory and visual stimuli in pollination of Lysichiton americanum (Araceae) by a staphylinid beetle. Madroño 33: 47-54.

Prieto, D. \& A. Cascante-Marín. 2017. Pollination by nitidulid beetles in the hemi-epiphytic aroid Monstera lentii (Araceae: Monsteroideae). Flora 231: 57-64.

Proctor, M., P. Yeo \& A. Lack. 1996. The Natural History of Pollination. Timber Press, Portland.

Ramírez, S., R. L. Dressler \& M. Ospinosa. 2002. Abejas euglosinas (Hymenoptera: Apidae) de la región Neotropical: Listado de especies con notas sobre su biología. Biota Colomb. 3: 7-118.

Ramírez, W. B. \& P. L. D. Gómez. 1978. Production of nectar and gums by flowers of Monstera deliciosa (Araceae) and of some species of Clusia (Guttiferae) collected by New World Trigona bees. Brenesia 14-15: 407-412.

Roubik, D. W. \& P. E. Hanson. 2004. Orchid Bees of Tropical America: Biology and Field Guide. INBio Press, Heredia, Costa Rica.

Ruiz-Idarraga, J. M. 2017. Biología Floral y Reproductiva de Anthurium kunthii y Anthurium caucavallense (Araceae) en un Fragmento de Bosque Seco de Colombia. Undergraduate thesis, Universidad del Valle, Cali.

Sakai, S., M. Kato \& H. Nagamasu. 2000. Artocarpus (Moraceae)-gall midge pollination mutualism mediated by a male-flower parasitic fungus. Amer. J. Bot. 87: 440-445.

Sato, A. A. W. \& M. Kato. 2017. Pollination system of Corylopsis gotoana (Hamamelidaceae) and its stonefly (Plecoptera) co-pollinator. Pl. Spec. Biol. 32: 440-447.

Schwerdtfeger, M., G. Gerlach \& R. Kaiser. 2002. Anthecology in the Neotropical genus Anthurium (Araceae): A preliminary report. Selbyana 23: 258-267.

Seymour, R. S. 2004. Dynamics and precision of thermoregulatory responses of eastern skunk cabbage Symplocarpus foetidus. Pl. Cell Environm. 27: 1014-1022.

Seymour, R. S. \& A. J. Blaylock. 1999. Switching off the heater: Influence of ambient temperature on thermoregulation by eastern skunk cabbage Symplocarpus foetidus. J. Exp. Bot. 50: 1525-1532.

Seymour, R. S. \& M. Gibernau. 2008. Respiration of thermogenic inflorescences of Philodendron melinonii: Natural pattern and responses to experimental temperatures. J. Exp. Bot. 59: 1353-1362.

Seymour, R. S., C. R. White \& M. Gibernau. 2003. Heat reward for insect pollinators. Nature 426: 243-244.

Seymour, R. S., Y. Ito, Y. Onda \& K. Ito. 2009. Effects of floral thermogenesis on pollen function in Asian skunk cabbage Symplocarpus renifolius. Biol. Lett. 5: 568-570.

Sultana, F., Y. G. Hu, M. J. Toda, K. Takenaka \& M. Yafuso. 2006. Phylogeny and classification of Colocasiomyia (Diptera, Drosophilidae), and its evolution of pollination mutualism with aroid plants. Syst. Entomol. 31: 684-702.

Takano, T. K., R. Repin, M. B. Mohamed \& M. J. Toda. 2012. Pollination mutualism between Alocasia macrorrhizos (Araceae) and two taxonomically undescribed Colocasiomyia species (Diptera: Drosophilidae) in Sabah, Borneo. Pl. Biol. 14: 555-564. 
Tam, S. M., P. C. Boyce, T. M. Upson, D. Barabé, A. Bruneau, F. Forest \& J. S. Parker. 2004. Intergeneric and intrafamilial phylogeny of subfamily Monsteroideae (Araceae) revealed by chloroplast $t r n L-F$ sequences. Amer. J. Bot. 91: 490-498.

Tan, K. H. \& R. Nishida. 2012. Methyl eugenol: Its occurrence, distribution, and role in nature, especially in relation to insect behavior and pollination. J. Insect Sci. 12: 1-74.

Tanaka, H. 2004. Reproductive biology of Lysichiton camtschatcense (Araceae) in Japan. Aroideana 27: 167-171.

Thompson, S. A. 2000. Araceae Juss._-Arum family. Pp. 128-142 in Flora of North America Editorial Committee (editors), Flora of North America North of Mexico, Vol. 22: Magnoliophyta: Alismatidae Arecidae, Commelinidae (in Part), and Zingiberidae. Oxford University Press, New York.

Thorington, K. K. 2000. Pollination and fruiting success in the eastern skunk cabbage Symplocarpus foetidus (L.) Salisb. ex Nutt. J. Biospheric Sci. 2. <https://www.mtholyoke.edu/courses/ mmcmenam/journal.html>, accessed 16 December 2017.

Toda, M. J. \& M. B. Lakim. 2011. Genus Colocasiomyia (Drosophilidae: Diptera) in Sabah, Bornean Malaysia: High species diversity and use of host aroid inflorescences. Entomol. Sci. 14: 262-270.

Uemura, S., K. Ohkawara, G. Kudo, N. Wada \& S. Higashi. 1993. Heat-production and cross-pollination of the Asian skunk cabbage Symplocarpus renifolius (Araceae). Amer. J. Bot. 80: 635-640.

Ulrich, S., M. Hesse, D. Bröderbauer, J. Bogner, M. Weber \& H. Halbritter. 2013. Calla palustris (Araceae): New palynological insights with special regard to its controversial systematic position and to closely related genera. Taxon 62 : 701-712.

Valerio, C. E. \& E. Villalobos. 1980. Polinización y eficiencia reproductiva en Anthurium scandens (Araceae). Brenesia 18: 137-146.

van Dulmen, A. 2001. Pollination and phenology of flowers in the canopy of two contrasting rain forest types in Amazonia, Colombia. Pl. Ecol. 153: 73-85.

Vogel, S. 1963. Das sexuelle Anlockungsprinzip der Catasetinen-und Stanhopeen-Blüten und die wahre Funktion ihres sogenannten Futtergewebes. Oesterr. Bot. Z. 110: 308-337.
Vogel, S. 1966. Parfümsammelnde Bienen als Bestäuber von Orchidaceen und Gloxinia. Österr. Bot. Z. 113: 302-361.

Whitten, W. M., H. G. Hills \& N. H. Williams. 1988. Occurrence of ipsdienol in floral fragrances. Phytochemistry 27: 2759-2760.

Willemstein, S. C. 1987. An Evolutionary Basis for Pollination Ecology. E. J. Brill, Leiden.

Williams, N. H. \& C. H. Dodson. 1972. Selective attraction of male euglossine bees to orchid floral fragrances and its importance in long distance pollen flow. Evolution 26: 84-95.

Williams, N. H. \& R. L. Dressler. 1976. Euglossine pollination of Spathiphyllum (Araceae). Selbyana 1: 349-356.

Willmer, P. 2011. Pollination and Floral Ecology. Princeton University Press, Princeton.

Willson, M. F. \& P. E. Hennon. 1997. The natural history of western skunk cabbage (Lysichiton americanum) in southeast Alaska. Canad. J. Bot. 75: 1022-1025.

Yadav, S. R. 1998. Adaptive significance of phenology and spadix architecture in Araceae of Western Ghats of India. Acta Bot. Yunnan., Suppl. 10: 31-40.

Yafuso, M. 1993. Thermogenesis of Alocasia odora (Araceae) and the role of Colocasiomyia flies (Diptera, Drosophilidae) as cross-pollinators. Environ. Entomol. 22: 601-606.

Yafuso, M., B. T. Viet \& S. Adaniya. 2015. Pollination mutualism between flower-breeding flies of the genus Colocasiomyia (Diptera, Drosophilidae) and their host plant routes of Araceae in Vietnam. Aroideana 38E: 94-106.

Zhu, G. \& T. B. Croat. 2004. Revision of Dracontium (Araceae). Ann. Missouri Bot. Gard. 91: 593-667.

Zucchi, R., S. F. Sakagami \& J. M. F. Camargo. 1969. Biological observations on a Neotropical parasocial bee, Eulaema nigrita, with a review on the biology of Euglossinae (Hymenoptera, Apidae). A comparative study. J. Fac. Sci. Hokkaido Univ., Ser. 6, Zool. 17: 271-379.

Zuluaga, A., K. Cameron, T. B. Croat \& M. M. Medecilo. 2015. Testing the monophyly of Spathiphyllum, and the relationship between Asian and tropical American species. Aroideana 38: 107-115. 